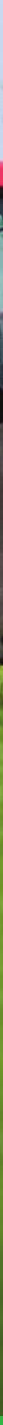

Scoping studie mestverdelingsmodule

Hans Kros en Piet Groenendijk

WAGENINGEN

UNIVERSITY \& RESEARCH 



\section{Scoping studie mestverdelingsmodule}

Hans Kros en Piet Groenendijk

Dit onderzoek is uitgevoerd door Wageningen Environmental Research (Alterra) in opdracht van het Planbureau voor de Leefomgeving (projectnummer 520043262).

Wageningen Environmental Research

Wageningen, juni 2017

Rapport 2817

ISSN 1566-7197 
Kros, J., P. Groenendijk, 2017. Scoping studie mestverdelingsmodule. Wageningen, Wageningen Environmental Research, Rapport 2817. 48 blz.; 1 fig.; 7 tab.; 31 ref.

In het kader van het Nationaal Water Model wordt gewerkt aan een nieuw te ontwikkelen Nationaal Nutriënten Model. Om dit model aan te kunnen passen, dient een geschikte mestverdelingsmodule te worden ontwikkeld dat aansluit bij de ambities van het Nationaal Nutriënten Model. Bij het huidige nationale nutriëntenmodel STONE wordt wat betreft de mestverdeling gebruikgemaakt van het model MAMBO. In hoeverre dit model aansluit bij de ambities van het Nationaal Nutriënten Model, is moeilijk op voorhand te beoordelen. Daarom is een scoping study uitgevoerd waarvan in dit rapport verslag wordt gedaan. Hiertoe is in eerste instantie een inventarisatie van eisen en criteria opgesteld op basis van een workshop met deskundigen. Vervolgens is een inventarisatie uitgevoerd van beschikbare mestverdelingsmodellen en -methoden, inclusief de huidige module MAMBO. Ten slotte is aan de hand van deze resultaten een advies opgesteld om te komen tot een operationele mestverdelingsmodule ten behoeve van het Nationaal Nutriënten Model.

Trefwoorden: Mest, mestverdeling, modellering, Nationaal Nutriëntenmodel

Dit rapport is gratis te downloaden van http://dx.doi.org/10.18174/418022 of op www.wur.nl/environmental-research (ga naar 'Wageningen Environmental Research' in de grijze balk onderaan). Wageningen Environmental Research verstrekt geen gedrukte exemplaren van rapporten.

(C) 2017 Wageningen Environmental Research (instituut binnen de rechtspersoon Stichting Wageningen Research), Postbus 47, 6700 AA Wageningen, T 03174807 00, E info.alterra@wur.nl, www.wur.nl/environmental-research. Wageningen Environmental Research is onderdeel van Wageningen University \& Research.

- Overname, verveelvoudiging of openbaarmaking van deze uitgave is toegestaan mits met duidelijke bronvermelding.

- Overname, verveelvoudiging of openbaarmaking is niet toegestaan voor commerciële doeleinden en/of geldelijk gewin.

- Overname, verveelvoudiging of openbaarmaking is niet toegestaan voor die gedeelten van deze uitgave waarvan duidelijk is dat de auteursrechten liggen bij derden en/of zijn voorbehouden.

Wageningen Environmental Research aanvaardt geen aansprakelijkheid voor eventuele schade voortvloeiend uit het gebruik van de resultaten van dit onderzoek of de toepassing van de adviezen.

Wageningen Environmental Research Rapport 2817 | ISSN 1566-7197

Foto omslag: Shutterstock 


\section{Inhoud}

$\begin{array}{ll}\text { Woord vooraf } & 5\end{array}$

$\begin{array}{ll}\text { Lijst van begrippen } & 7\end{array}$

$\begin{array}{ll}\text { Samenvatting } & 9\end{array}$

$\begin{array}{lrr}1 & \text { Inleiding } & 13\end{array}$

1.1 Achtergrond 13

1.2 Doelstelling $\quad 13$

$\begin{array}{lll}1.3 & \text { Opzet scoping study } & 14\end{array}$

$\begin{array}{lll}1.4 & \text { Leeswijzer } & 14\end{array}$

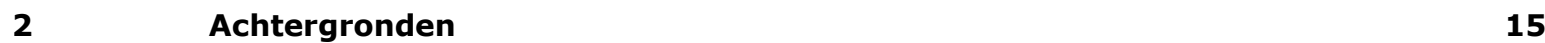

$2.1 \quad H u i d i g e$ mest- en ammoniakmodellen en beleidsterreinen $\quad 15$

2.2 Gerelateerde Europese richtlijnen en hun onderlinge relaties $\quad 18$

2.2.1 Relatie KRW met Nitraatrichtlijn en Natura $2000 \quad 18$

$\begin{array}{ll}\text { 2.2.2 Relatie mestverdeling met de PAS } & 19\end{array}$

$\begin{array}{llr}3 & \text { Inventarisatie van eisen en criteria } & 20\end{array}$

$3.1 \quad$ Resultaten workshop $\quad 20$

$\begin{array}{ll}3.1 .1 & \text { Inventarisatie van eisen en criteria }\end{array}$

4 Inventarisatie van huidige mestverdelingsmodellen en/of methodieken 25

$\begin{array}{lll}4.1 & \text { MAMBO } & 25\end{array}$

4.1.1 Modelbeschrijving 25

$\begin{array}{ll}4.1 .2 \text { Modelinput } & 26\end{array}$

$\begin{array}{ll}4.1 .3 \text { Modeloutput } & 27\end{array}$

4.1.4 Scenario's/maatregelen $\quad 27$

4.1.5 Afstemming en operationele aspecten $\quad 27$

4.2 INITIATOR $\quad 29$

4.2.1 Modelbeschrijving $\quad 29$

4.2.2 Modelinput 30

4.2.3 Modeloutput 31

4.2.4 Scenario's/maatregelen 31

4.2.5 Afstemming en operationele aspecten 31

$\begin{array}{lll}4.3 & \text { Overige } & 33\end{array}$

$\begin{array}{lll}4.4 & \text { Adviezen } & 33\end{array}$

$5 \quad$ Conclusies en aanbevelingen $\quad 36$

$\begin{array}{ll}\text { Literatuur } & 38\end{array}$

Bijlage 1 Programma, deelnemers en verslag van de workshop 40

Bijlage 2 Verkenning van MITERRA en INITIATOR ten behoeve van $\begin{array}{ll}\text { inzet voor de NEMA } & 45\end{array}$ 



\section{Woord vooraf}

Het Planbureau voor de Leefomgeving is mede opdrachtgever voor de ontwikkeling van een Nationaal Nutriëntenmodel waarmee onder andere evaluaties van het waterkwaliteitsbeleid ondersteund zullen worden. Het Nationaal Nutriëntenmodel maakt gebruikt van informatie over bemesting op landbouwgronden, dat door een extern model gegenereerd dient te worden of door een module binnen het genoemde model. Omdat er op dit moment nog niet is voorzien in een mestverdelingsmodule en er verschillende modellen in omloop zijn, is een scoping study uitgevoerd, waarin de voor- en nadelen van de verschillende modellen op een rij worden gezet. Aan de hand van deze scoping study moet een definitieve keuze voor de in te zetten modellen gemaakt kunnen worden.

De conceptversie is uitgebreid voorzien van dankbaar commentaar door Gerard Velthof, Jan Peter Lesschen (WEnR), Tanja de Koeijer, Willem Pieter Blokland, Harry Luesink en Krijn Poppe (WECR), Gerard Ros (AGV, NMI), Sietske van der Sluis en Aaldrik Tiktak (PBL). 


\section{Lijst van begrippen}

\begin{tabular}{|c|c|}
\hline Begrip & Omschrijving \\
\hline AERIUS & Instrument binnen de PAS gericht op gebiedsgerichte aanpak $\mathrm{NO}_{x}$ en $\mathrm{NH}_{3}$ emissie \\
\hline BBPR & BedrijfsBegrotingsProgramma Rundvee \\
\hline BIN & Bedrijven Informatie Netwerk \\
\hline BO & BeleidsondersteundOnderzoek, gefinancierd door het Ministerie van EZ \\
\hline BRP & Basis Registratie Percelen \\
\hline CDM & Commissie Deskundigen Meststoffen \\
\hline DRAM & Dutch Regionalised Agricultural Model \\
\hline ER & EmissieRegistratie \\
\hline GIAB / GIAB-plus & Geografisch Informatiesysteem Agrarische Bedrijven, waarbij plus staat voor nevenvestigingen \\
\hline INITIATOR & Integrated Nitrogen Impact Assessment Tool on a Regional Scale \\
\hline KB & KennisBasisonderzoek, gefinancierd door het Ministerie van EZ \\
\hline LHM & Landelijk Hydrologisch Model \\
\hline MAMBO & Mest en Ammoniak Model voor Beleidsondersteunend Onderzoek \\
\hline MEBOT & Gewasmodule voor akker- en tuinbouwgewassen \\
\hline MINIP & Model voor bodemorganische stof \\
\hline MITERRA-NL & Model voor berekening mestverdeling, ammoniak- en broeikasemissies \\
\hline NAP & Nitraat ActieProgramma van de Nitraatrichtlijn \\
\hline NDICEA & Model om de stikstofleverantie van de bodem te bepalen \\
\hline NEMA & Het Nationaal Emissiemodel voor Ammoniak \\
\hline NHI-wq & Het Nationaal Hydrologisch Instrumentarium \\
\hline NNM & Nationaal Nutriënten Model, beoogd opvolger STONE \\
\hline OPS & Operational Priority Substances model. atmosferisch transportmodel \\
\hline PAS & Programma Aanpak Stikstof \\
\hline PLEASE & Phosphate LEAching from Soils to the Environment \\
\hline QBGM & Quality Based generic GAMS Modelling \\
\hline STONE & Het nationale nutriëntenemissie model \\
\hline SWAP-WOFOST & Agrohydrologisch model (SWAP) - gewasgroeimodel (WOFOST) \\
\hline SGBP & Stroomgebiedbeheerplannen \\
\hline WOG-WOD & $\begin{array}{l}\text { Rekeninstrumentarium ontwikkeld door de CDM-Werkgroep Onderbouwing Gebruiksnormen } \\
\text { (WOG) en Derogatie (WOD) }\end{array}$ \\
\hline WUM & Werkgroep Uniformering Mestcijfers. Levert o.a. excreties \\
\hline
\end{tabular}




\section{Samenvatting}

In het kader van het Nationaal Water Model wordt gewerkt aan een nieuw te ontwikkelen Nationaal Nutriënten Model. Voor de toepassing van dit model dient een mestverdelingsmodule te worden ontwikkeld die aansluit bij de ambities van het Nationaal Nutriënten Model (NNM). Bij het huidige nationale nutriëntenmodel STONE wordt voor de mestverdeling gebruikgemaakt van het model MAMBO. In hoeverre dit model aansluit bij de ambities van het Nationaal Nutriënten Model, is moeilijk op voorhand te beoordelen. Daarom is een scoping study uitgevoerd aan de hand van de volgende onderzoekswensen:

1. Inventariseer de eisen en criteria ten aanzien van een mestverdelingsmodule die door het Nationaal Nutriëntenmodel worden gesteld, zowel wat betreft de basisprognose (ex post) als een model voor de toekomst (ex ante).

2. Inventariseer welke modellen voorhanden zijn aan de hand van een korte beschrijving van doel, werkwijze, uitvoer en toepassings- en geldigheidsgebied.

3. Beoordeel aan de hand van onder vraag 1 geïdentificeerde criteria de mate van geschiktheid van bestaande mestverdelingsmodellen.

Doel van deze studie is om te komen tot een advies ten behoeve van nader te ontwikkelen mestverdelingsmodules voor het Nationaal Nutriëntenmodel. Hierbij is, waar mogelijk, onderscheid gemaakt tussen een model voor de basisprognose (ex post) en een flexibeler model, waarmee snel en in een kort tijdbestek varianten kunnen worden doorgerekend voor toekomstverkenningen (ex ante). Meer specifiek gaat het hierbij om het:

- in kaart brengen van de eisen aan en criteria die vanuit het Nationaal Nutriëntenmodel worden gesteld ten aanzien van de mestverdeling;

- inventariseren van bestaande mestverdelingsmodellen met onderscheid tussen ex-post- en ex- anteanalyses;

- uitwerken van een concreet advies. In dit advies wordt ook aangegeven hoe het model voor ex- anteanalyses zich verhoudt tot het model voor de basisprognose.

Allereerst is hiertoe in hoofdstuk 2 een overzicht gegeven van de huidige mest- en ammoniakmodellen, waarbij de mestverdeling een cruciale rol speelt en die worden toegepast ter ondersteuning van beleidsvragen en/of -rapportages van de ministeries van Economische Zaken en Infrastructuur \& Milieu, zoals:

1. Het mestbeleid (Evaluatie Meststoffenwet, Nitraatactieprogramma voor de Nitraatrichtlijn, NAP).

2. Het waterbeleid (Evaluatie stroomgebiedbeheerplannen voor de KaderRichtlijn Water, KRW; drinkwaterkwaliteit, verkenningen effectiviteit maatregelen).

3. Het ammoniakbeleid (Programma Aanpak Stikstof, PAS).

4. Rapportage van emissies naar lucht en water uit de landbouw door EmissieRegistratie (ER).

De rapportages en de modeltoepassingen die hieraan ten grondslag liggen zijn met elkaar verbonden, maar niet altijd optimaal op elkaar afgestemd. Zo is de KRW nauw verbonden met de Habitat Richtlijn (Natura 2000) en de Nitraatrichtlijn (NR), maar de KRW werkt met zesjaarlijkse stroomgebiedbeheerplannen (SGBP) (op dit moment lopen de $2^{\mathrm{e}}$ generatie SGBP, 2016-2021), de Habitat Richtlijn hanteert eveneens zesjaarlijkse beheerplannen (op dit moment lopen de $3^{\mathrm{e}}$ beheerplannen, 2014-2019), terwijl de NR werkt met vierjaarlijkse actieplannen (op dit moment wordt gewerkt aan het $5^{\mathrm{e}}$ actieprogramma, 2014-2017). Dit vraagt om extra aandacht en afstemming wat betreft de gebruikte modellen en toepassingen.

In hoofdstuk 3 wordt een overzicht gegeven van de inventarisatie van eisen en criteria op basis van de gehouden workshop. Aspecten die tijdens de workshop aan de orde zijn geweest, betroffen:

- Herkomst en actualiteit van gegevens.

- Ruimtelijke schaal en flexibiliteit voor aanpassing in verandering in ruimtelijke aggregaties, consistentie van resultaten bij gebruik voor verschillende ruimtelijke schalen. 
- Flexibiliteit ten aanzien van aanpassingen en uitbreidingen.

- Doorlooptijd van vraag tot antwoord (levering).

- Kosten voor ontwikkeling, beheer en onderhoud, toepassing, overhead.

- Een model dat zowel geschikt is voor zowel basisprognose als voor toekomstverkenningen of twee aparte modellen die onderling consistent zijn.

- Geschikt voor ex-anteanalyses en toekomstverkenningen.

- Afstemming met andere partijen en op modellen waarvan invoer wordt gebruikt (RVO, CBS, CPB, etc.).

- Afstemming met andere partijen die belang hebben bij mestgegevens (EmissieRegistratie)

- Mate waarin de wetenschappelijk kwaliteit is geborgd.

- Operationaliteit en continuïteit zijn organisatorisch geborgd.

- Het zelf toepassen, bijv. via een webapplicatie, van de mestverdelingsmodule door derden.

De wensen van de ministeries van Economische Zaken (EZ) en Infrastructuur \& Milieu (I\&M) ten aanzien van de mestverdelingsmodule betreffen:

- Een module die goed, actueel en realistisch de huidige situatie ten aanzien van de mestverdeling beschrijft.

- Flexibel, te allen tijden operationeel, snel te actualiseren met geringe inspanning, met weglating van niet-essentiële details.

- Vormt een consistent geheel met de overige modellen/methodieken uit de gehele "mestketen" van productie t/m emissies naar lucht (NEMA, ER) en water (STONE, ER).

- Een ruimtelijk detail dat afhankelijk is van de beoogde vraag.

- Integratie met beleidssporen ( $3^{\mathrm{e}}$ stroomgebiedsbeheerplannen KRW (SGPB, 2022-2027), $6^{\mathrm{e}}$ Nitraat Actieprogramma (2018-2021) ( $7^{\mathrm{e}}$ start tegelijk met 3e SGBP), $3^{\mathrm{e}}$ beheersplannen Natura 2000 (2020-2015)) moet efficiënter en effectiever worden.

- Eenduidige aansturing is noodzakelijk om (i) kosten te beperken en (ii) consistentie te vergroten.

De wensen van waterschappen en provincies betreffen:

- Jaarlijks een ruimtelijk expliciet bestand met mesttoediening op perceelniveau. Zowel voor de huidige situatie als toekomstscenario's.

- Aansluiting bij de praktijk. Zo is er bij Waterschappen en overige regionale instanties veel gebiedsinformatie beschikbaar die beter benut zou kunnen worden.

- Mest is breder dan dierlijke mest; kunstmest en overige organische producten zijn ook van groot belang.

Eisen die vanuit de werkgroep rondom het NNM zijn gesteld ten aanzien van de mestverdelingsmodule betreffen:

- Informatie over gehalten aan organische stof, $\mathrm{N}$-mineraal, $\mathrm{N}$-effectief, $\mathrm{N}$-organisch, P-mineraal en P-organisch van de verschillende mestsoorten.

- Afstemming indeling gewassen/vruchtwisseling bij berekening van mestverdeling en NNM is nodig. Rekening houden met opbrengst-afhankelijk bemesten (equivalente maatregel).

- Behoefte aan een historische en toekomstige consistente tijdreeks (focus op een specifiek jaar: risico's i.v.m. toevallige effecten).

- Zo mogelijk een verdeling binnen het jaar om rekening te houden met praktijkomstandigheden en met scenario's waarin effecten van toepassingsperioden en precisiebemesting worden berekend.

- Naast dierlijke mest ook aanvoer van overige organische mestproducten (deze worden in MAMBO/STONE niet meegenomen).

- Mogelijkheden om opties voor overbenutting van gebruiksruimte in te stellen.

- Consistentie in aannamen t.a.v. P-status (Pw/PAL ivm P-gebruiksnorm) en een realistische schatting van de verwachte ontwikkeling van de fosfaattoestand als gevolg van toekomstige mestgiften en P-overschotten, waarbij rekening gehouden wordt met de wettelijke gebruiksvoorschriften.

- Consistentie in gehanteerde kunstmest hoeveelheden. Er circuleren ruwweg twee varianten: BIN en kunstmeststatistiek van WEcR. Hierbij betreft de BIN-variant de ruimtelijke differentiatie van de landelijke hoeveelheid, maar deze tellen niet op tot de totalen van de kunstmeststatistiek. Op dit moment word er in de Taakgroep Landbouw ernstig getwijfeld aan de kwaliteit van de kunstmeststatistiek. Er wordt aan gedacht over te stappen op BIN. 
In hoofdstuk 4 wordt een overzicht gegeven van de geïnventariseerde mestverdelingsmodellen en methoden. Het gaat hierbij met name om een uitgebreid overzicht van de huidige module MAMBO en de mestverdelingsmodule van het model INITIATOR. Daarnaast is beknopt aangegeven van overige mestverdelingsmodellen.

Ten slotte worden in hoofdstuk 4 de resultaten geëvalueerd en bediscussieerd en wordt er een advies gegeven om te komen tot een operationele versie voor 2018. Hierbij is achtereenvolgens ingegaan op de modeleisen, datagebruik en -beschikbaarheid, afstemming tussen organisaties en beleidssporen en aansturing en organisatiestructuur.

De belangrijkste conclusies op basis van de workshop zijn:

- Streef naar een goedkoop en efficiënt in te zetten model voor mestverdeling, waarvan de kosten voor beheer, onderhoud, update en toepassing transparant zijn. Het beeld bestaat dat de werkwijze waarin MAMBO ter gelegenheid van bepaalde studies werd geüpdatet (ER 2013, EMW 2016), leidde tot kosten die zwaar drukten op het budget van de betreffende studies.

- Zorg voor consistentie in mestgegevens die gebruikt worden voor ex-post- en ex-antestudies.

- Maak eenduidige keuzes voor gegevensbronnen ten aanzien van gehalten in mest, kunstmestgebruik, landgebruik, emissiefactoren en dergelijke.

- Zorg voor een goede aansluiting op rekenmodellen die gebruikmaken van de mestgegevens, zowel wat betreft de ruimtelijke als de temporele schaal.

De belangrijkste aanbevelingen betreffen:

- Breng de verantwoordelijkheid voor ontwikkeling, toepassing en borging onder bij een stuurgroep met daarin vertegenwoordigers van de ministeries en het RIVM.

- Zorg voor draagvlak bij stakeholders en eindgebruikers, zoals de Waterschappen.

- Maak onderscheid in de rekenschaal en de presentatieschaal en stem de presentatieschaal af op zowel landelijke (t.b.v. ministeries) als regionale beleidsstudies (t.b.v. Waterschappen).

- Breng de ex-ante- en ex-postmodellering zo veel mogelijk onder in het zelfde modelsysteem.

- Zorg voor directe aansluiting op NNM en AERIUS (vermijd tweetrapsprocedure).

- Bouw zo veel mogelijk voort op de huidige (data)structuur en voer eventuele wijzigingen stap voor stap door. 


\section{$1 \quad$ Inleiding}

\subsection{Achtergrond}

De stuurgroep van het Nationaal Water Model heeft in 2016 besloten ${ }^{1}$ om binnen het kader van het Nationaal Water Model (NWM) een samenhangend waterkwaliteitsinstrumentarium voor nutriënten te ontwikkelen (NHI-wq), hierna te noemen Nationaal Nutriënten Model (NNM). Hiermee wordt onder andere beoogd een aantal knelpunten die bij het huidige model, STONE (Groenendijk et al. 2015), is geconstateerd, op te lossen. Hierbij is echter geen aandacht voor de mestverdeling. Het nieuw te ontwikkelen NNM zal echter specifieke eisen stellen aan de aansluiting op een volwaardig en geaccepteerd model voor mestverdeling op een schaalniveau dat is afgestemd op de beoogde doelen. In het plan van aanpak wordt ervan uitgegaan dat gebruik wordt gemaakt van de huidige bemestingsgegevens van MAMBO (Kruseman et al. 2013; De Koeijer et al. 2017) die worden toegepast in STONE. In de huidige opzet worden de MAMBO-resultaten echter middels een nabewerkingsmodule precies afgestemd op de STONE-plot schematisering (De Koeijer et al. 2014). In hoeverre dit aansluit bij de ambities van het NNM, met name met betrekking tot de schematisatie, is moeilijk op voorhand te beoordelen.

Door het Planbureau voor de Leefomgeving is daarom aan Wageningen Environmental Research gevraagd om een scoping study uit te voeren naar een geschikte mestverdelingsmodule voor het Nationaal Nutriëntenmodel. Het gaat hierbij om zowel de basisprognose (ex post) als de toekomstverkenningen (ex ante). Al of niet ondergebracht in een model, maar wel optimaal op elkaar afgestemd.

Deze scoping study is uitgevoerd aan de hand van de volgende onderzoekswensen:

1. Inventariseer de eisen en criteria ten aanzien van een mestverdelingsmodule die door het Nationaal Nutriëntenmodel worden gesteld, zowel wat betreft de basisprognose (ex post) als een model voor de toekomst (ex ante).

2. Inventariseer welke modellen voorhanden zijn aan de hand van een korte beschrijving van doel, werkwijze, uitvoer en toepassings- en geldigheidsgebied.

3. Beoordeel aan de hand van onder vraag 1 geïdentificeerde criteria de mate van geschiktheid van bestaande mestverdelingsmodellen.

\subsection{Doelstelling}

Dit project beoogt het opstellen van een advies ten behoeve van nader te ontwikkelen mestverdelingsmodules voor het Nationaal Nutriëntenmodel. Hierbij is, waar mogelijk, onderscheid gemaakt tussen een model voor de basisprognose (ex post) en een flexibeler model, waarmee snel en in kort tijdbestek varianten kunnen worden doorgerekend, voor toekomstverkenningen (ex ante). Meer specifiek gaat het hierbij om het:

- In kaart brengen van de eisen aan en criteria die vanuit het Nationaal Nutriëntenmodel worden gesteld ten aanzien van de mestverdeling.

- Inventariseren van bestaande mestverdelingsmodellen met onderscheid tussen ex-post- en ex-anteanalyses.

- Uitwerken van een concreet advies. In dit advies wordt ook aangegeven hoe het model voor ex-anteanalyses zich verhoudt tot het model voor de basisprognose.

\footnotetext{
${ }^{1}$ Waterkwaliteit binnen het Nationaal Water Model. Plan van aanpak 2016-2018 voor het Landelijk Nutriënten Instrumentarium.
} 


\subsection{Opzet scoping study}

Het project is via de volgende drie fasen uitgevoerd.

\section{Fase 1: inventarisatie van eisen en criteria}

Deze fase is begonnen met het organiseren van een workshop, waarbij met name deskundigen van Planbureau voor de Leefomgeving (PBL), EmissieRegistratie (ER), Rijksdienst voor Ondernemend Nederland (RVO), Centraal Bureau voor de Statistiek (CBS), Wageningen University \& Research (WUR), Waterschappen en Provincies zijn betrokken. Met deze workshop werd beoogd om: (i) scherp te krijgen aan welke eisen de mestverdelingsmodules dienen te voldoen (met onderscheid tussen ex post en ex ante), (ii) met partijen die belang hebben bij mestgegevens en (iii) afstemming te realiseren met partijen waarvan invoergegevens worden gebruikt.

Op basis van de resultaten van deze workshop is een inventarisatie gemaakt van de eisen en criteria waaraan de mestverdelingsmodule zo veel mogelijk dient te voldoen.

Fase 2: inventarisatie van beschikbare modellen

Tijdens deze fase is een inventarisatie uitgevoerd van beschikbare mestverdelingsmodellen en -methoden, inclusief de huidige module MAMBO. Vervolgens zijn de geïnventariseerde modellen en/of methode gescoord op de mate waarin wordt voldaan aan de tijdens fase 1 opgestelde eisen en criteria.

\section{Fase 3: uitwerken van een concreet advies}

In deze fase is aan de hand van de resultaten van fase 1 en 2 een advies opgesteld. In dit advies is deels een tijdsplanning opgenomen om een operationele versie voor 2018 gereed te hebben, zodat aangesloten kan worden bij de huidige NWM.

Globaal zijn er op voorhand drie mogelijke opties te identificeren:

1. MAMBO blijven gebruiken voor de basisprognose (ex post) en voorzieningen treffen waarmee het model snel te updaten is en met weinig inspanning nieuwe ontwikkelingen en toekomstverkenningen (ex ante) zijn door te rekenen.

2. MAMBO blijven gebruiken voor de basisprognose (ex post) en het ontwikkelen van een nieuwe module voor toekomstverkenningen (ex ante) die naadloos aansluit op MAMBO.

3. Een volledige nieuw te ontwikkelen model dat geschikt is voor zowel de basisprognose (ex post) (dus vervanging van MAMBO) als voor de toekomstverkenningen (ex ante).

\subsection{Leeswijzer}

In hoofdstuk 2 wordt een overzicht gegeven van de huidige mest- en ammoniakmodellen en hun rol bij diverse beleidsthema's. Vervolgens wordt in hoofdstuk 3 een overzicht gegeven van de inventarisatie van eisen aan en criteria op basis van de gehouden workshop. In hoofdstuk 4 wordt een overzicht gegeven van de geïnventariseerde modellen. Ten slotte worden in hoofdstuk 5 de resultaten geëvalueerd en bediscussieerd en wordt er een advies gegeven om te komen tot een operationele versie voor 2018 . 


\section{Achtergronden}

\subsection{Huidige mest- en ammoniakmodellen en beleidsterreinen}

Omdat de mestverdeling zowel wat betreft beleid als wat betreft modellen nauw verweven is met de ammoniakproblematiek, wordt in dit hoofdstuk zowel ingegaan op mestmodellen als op ammoniakmodellen. De betrouwbaarheid van de uitkomsten van deze modellen wordt in hoge mate bepaald door de nauwkeurigheid waarmee de mestverdeling wordt berekend.

Mest- en ammoniakmodellen worden voor verschillende doeleinden en voor verschillende opdrachtgevers toegepast in Nederland. In de voorbij jaren zijn vele verschillende, maar (deels) overlappende modellen ontwikkeld. Dat komt door de decentralisatie van het beleid (bevoegdheden en verplichtingen zijn overgeheveld van de nationale overheden naar regionale overheden en de Europese Commissie), de privatisering van onderzoeksinstellingen (overheden hebben minder inhoudelijke invloed op die instellingen gekregen; en een model wordt gezien als troef om opdrachten binnen te halen) en door de toenemende invloed (en opdrachten) van het bedrijfsleven, waar de geprivatiseerde instellingen op in spelen.

In Tabel 1 is een overzicht gegeven van de belangrijkste modellen die in de periode 2013-2016 zijn gebruikt voor mestvraagstukken.

Tabel 1 In de periode 2013-2016 gebruikte modellen voor mestvraagstukken.

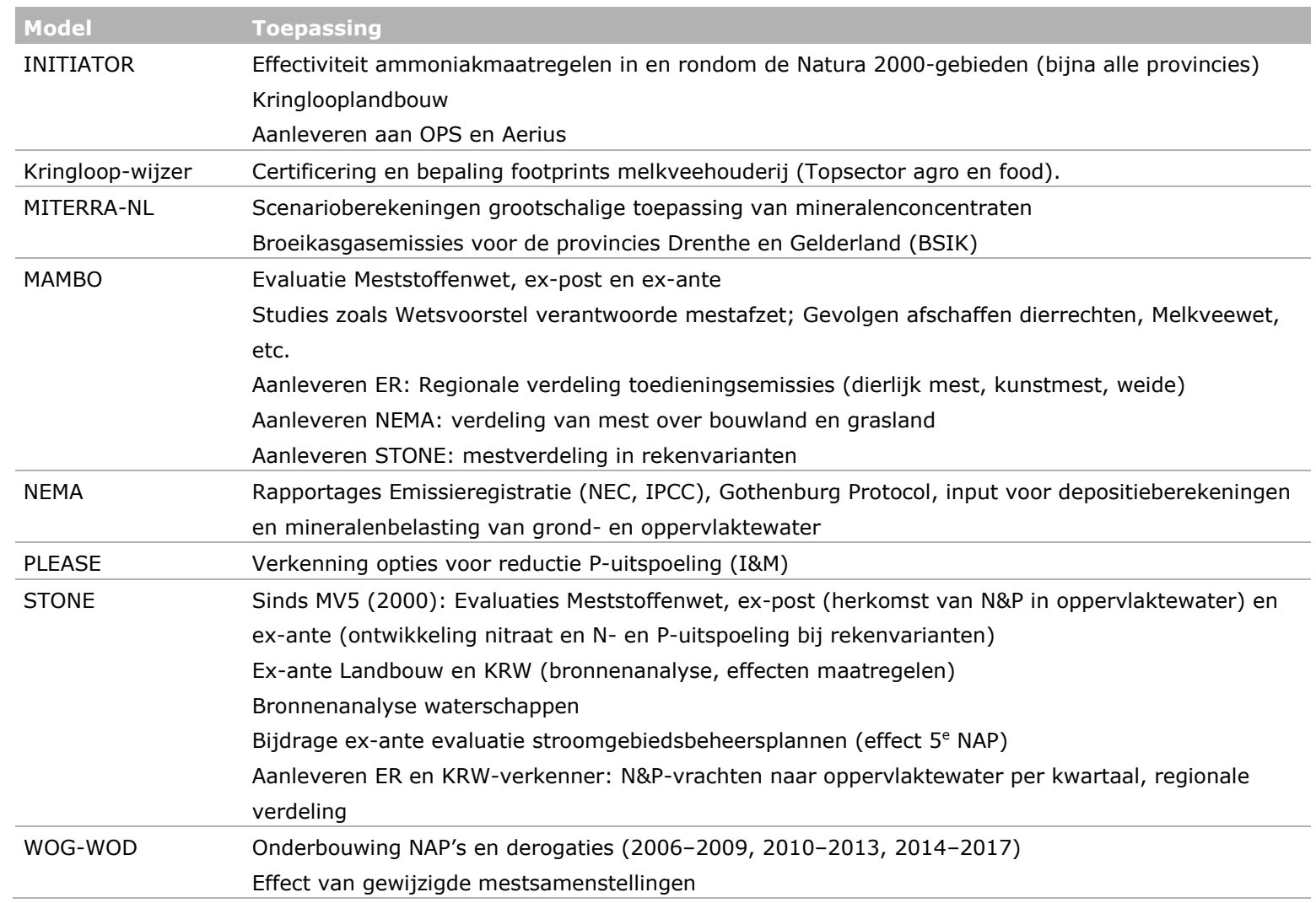


Naast geringe centrale sturing is de bezuiniging bij de nationale overheden een andere ontwikkeling. Ministeries hebben steeds minder geld voor opdrachten; het moet sneller en goedkoper. De prijskwaliteitverhouding is daarbij verschoven. Het ministerie van EZ is van oudsher een gebruiker van de resultaten van mest- en ammoniakmodellen. Maar door de voornoemde verschuivingen en veranderingen in verantwoordelijkheden en verplichtingen is dat gebruik veranderd en verminderd. De huidige mest- en ammoniakmodellen worden vanuit beleidsvragen en -toepassingen van de ministeries van EZ en I\&M toegepast voor:

1. Het mestbeleid (Evaluatie MestWet, Nitraatactieprogramma voor de Nitraatrichtlijn, NAP).

2. Het waterbeleid (Evaluatie stroomgebiedbeheerplannen voor de KaderRichtlijn Water, KRW; drinkwaterkwaliteit, verkenningen effectiviteit maatregelen).

3. Het ammoniakbeleid (Programma Aanpak Stikstof, PAS).

4. Rapportage van emissies naar lucht en water uit de landbouw door EmissieRegistratie (ER).

Bij EZ wordt onderscheid gemaakt in modeltoepassingen in het kader van i) verplichtingen/ toezeggingen, ii) onderbouwing van beleid en iii) evaluaties, scenariostudies en onderzoek. Bij de bespreking van verschillende beleidsvelden wordt deze driedeling ook toegepast.

Mestbeleid (ministerie van EZ)

In het kader van het mestbeleid gelden de volgende nationale en internationale verplichtingen:

- De monitoring van de mestproductie en -plaatsing in Nederland op basis van RVO-gegevens en CBSgegevens. Het stikstof- en fosfaatoverschot afgeleid uit CBS-statistieken is een prestatie-indicator van het mestbeleid die jaarlijks aan de Tweede Kamer wordt gerapporteerd.

- Het jaarlijks vaststellen van de mestverwerkingspercentages en het regionale mestoverschot gebaseerd op de recentste data en informatie over mestproductie en -plaatsing. Waarbij excreties van de Werkgroep Uniformering berekening Mest- en mineralencijfers (WUM; WUM (2010)) gebruikt worden voor de mestproductie uitgedrukt in fosfaat en van WUM-NEMA (National Emission Model for Agriculture; Vonk et al. (2016)) voor mestproductie uitgedrukt in stikstof (WUM voor excretie en NEMA voor gasvormige stikstofverliezen).

Ter ondersteuning zijn hier de volgende modellen gehanteerd:

- WUM en NEMA voor bepalen mestproductie.

- MAMBO is tot 2014 gebruikt voor de monitoring mestmarkt.

- Mestverwerkingspercentages: WUM-NEMA en CBS-berekeningen als basis voor vaststellen mestverwerkingspercentages en mogelijk monitoring mestmarkt.

Hiermee zijn de volgende evaluaties, scenariostudies en ad hoc onderzoeken uitgevoerd:

- De Meststoffenwet wordt elke 4-6 jaar geëvalueerd (Art. 46). In de evaluaties voor 2002, 2004 en 2007 zijn de modellen CLEAN (Van Tol et al. (2002); voor bemesting) en STONE (voor uitspoeling) gebruikt voor ex-post- en ex-ante-evaluaties en voor 2012 de modellen MAMBO (voor bemesting) en STONE (voor uitspoeling). Het doel van de evaluatie is het nagaan van de doeltreffendheid van de Meststoffenwet en de effecten ervan in de praktijk.

- In de ex-ante-evaluatie mestbeleid uit 2016 (EMW 2016) zijn berekeningen uitgevoerd met MAMBO en STONE (Schoumans et al. 2017). In de ex post is naast MAMBO en STONE gebruikgemaakt van NEMA (Velthof et al. 2017).

- Op ad-hoc basis worden evaluaties/studies uitgevoerd voor EZ en I\&M waarin modellen worden toegepast, zoals voor de MER-rapportage $5^{\mathrm{e}}$ NAP (WOG-WOD; Schroder et al. (2011), MAMBO, STONE) en grootschalige toepassing mineralenconcentraten (MITERRA-NL), effectiviteit van fosfaatmaatregelen (PLEASE; Van der Salm et al. (2011)/STONE), opgave van landbouw voor KRW en effecten maatregelen (STONE).

- In onderzoek (waaronder het Beleidsonderzoek (BO) en Kennisbasisonderzoek(KB) binnen Wageningen University \& Research) voor EZ worden soms onderzoeksmodellen gebruikt, bijvoorbeeld over organische stof, bemesting, fosfaataccumulatie en emissies naar het milieu. Dit betreft soms de hierboven genoemde modellen, maar ook andere modellen zoals ANIMO, SWAPWOFOST, INITIATOR, PLEASE, MINIP, NDICEA, MEBOT en BBPR (zie bijv. Velthof en Grinsven, 2006). 
Ammoniakbeleid (ministerie van EZ, provincies)

In het kader van het ammoniakbeleid gelden de volgende nationale en internationale verplichtingen:

- NEMA voor landelijke emissies t.b.v. de verplichte rapportages in kader NEC en Gothenborg protocol, Kyoto en IPCC.

- Het ministerie van EZ is verantwoordelijk voor PAS en heeft daarvoor het model AERIUS (EL\&I, 2012) laten ontwikkelen. Het model AERIUS wordt niet verder behandeld in deze notitie, maar wel de modellen die AERIUS voeden. AERIUS gaat allerlei ontwikkelingen door. Op dit moment levert ER aan AERIUS emissies op gedetailleerde ruimtelijke schaal. De emissies uit stallen en mestopslagen worden berekend op nationale schaal met het model NEMA-stalemissie en vervolgens neergeschaald naar bedrijfsniveau op basis van stalgegevens uit GIAB-plus en dieraantallen uit I\&R. De emissies van mesttoediening worden berekend door de nationale NEMA-mesttoediening vervolgens neergeschaald naar een $500 \mathrm{~m} \times 500 \mathrm{~m}$ resolutie met behulp van MAMBO (dit gebeurt een keer per drie jaar).

- Emissieregistratie is verantwoordelijk voor datamanagement rond AERIUS.

Ter ondersteuning zijn hier de volgende modellen gehanteerd:

- NEMA voor bepalen op landelijke schaal.

- MAMBO voor het neerschalen van de landelijke emissie naar een landelijk $500 \mathrm{~m} \times 500 \mathrm{~m}$ grid.

- AERIUS voor de vergunningverlening ammoniaemissie en het monitoren van ammoniakemissie.

- MITERRA-NL (Lesschen et al. 2011) en INITIATOR (De Vries et al. 2003; Kros et al. 2011) voor specifieke ruimtelijk expliciet evaluaties ten behoeve van provinciaal beleid.

Hiermee zijn de volgende evaluaties, scenariostudies en ad hoc onderzoeken uitgevoerd:

- Voor evaluaties en scenariostudies kunnen verschillende modellen worden gebruikt. NEMA is geschikt voor evaluaties en scenariostudies op nationale schaal. MAMBO, MITERRA-NL en INITIATOR zijn ruimtelijk expliciet en kunnen ook emissies van zware metalen naar de bodem en de ruimtelijke verdeling van (kunst)mest berekenen. Alle drie de modellen gebruiken de NEMA-methodiek voor berekeningen van ammoniakemissie. De mestverdelingsmodule van MAMBO is het meest gedetailleerd (mestsoort-specifiek) en het best onderbouwd. MITERRA-NL en INITIATOR zijn sneller en flexibeler toepasbaar. De benodigde tijd en kosten zijn hoger voor MAMBO dan voor MITERRA-NL en INITIATOR.

- Zoals bij modellen voor het mestbeleid genoemd, kan de keuze voor modellen die ingezet worden voor een bepaalde onderzoeksvraag of evaluatie gemaakt worden bij de opdrachtverlening.

Uitspoeling uit de landbouw naar oppervlaktewater (ministeries van I\&M en EZ, Waterschappen) In het kader van het ammoniakbeleid gelden de volgende nationale en internationale verplichtingen:

- Evaluatie stroomgebiedenbeheerplannen met betrekking tot de Kaderrichtlijnwater.

- Emissie Registratie: Registreren/up-to-date houden van emissies.

- Via upload naar Emissie Registratie de beschikking hebben over informatie voor internationale rapportageverplichtingen.

Ter ondersteuning zijn hier de volgende modellen gehanteerd:

- STONE is het nationaal instrumentarium voor berekening op landelijk niveau van belasting van grond- en oppervlaktewater met stikstof en fosfaat uit de landbouw.

- MAMBO levert bemestingsinput voor STONE.

- Waterschappen hanteren ieder hun eigen methodiek voor het opstellen van watersysteemanalyses/waterbalansen, gebaseerd op grondwater- en oppervlaktewatermodellen. Dit betreft een hele set aan modellen die varieert per waterschap.

Hiermee zijn de volgende evaluaties, scenariostudies en ad-hoc-onderzoeken uitgevoerd:

- STONE is o.a. ingezet voor het vaststellen van de KRW opgave van de landbouw ten aanzien van nutriëntenbelastingen van regionale oppervlaktewateren (Groenendijk et al. 2016).

- KRW-verkenner maakt gebruik van informatie uit EmissieRegistratie, STONE en het Landelijke Hydrologisch Model (LHM) voor de schatting van wijzigingen in Ecologische KwaliteitsRatio (EKRscores) van waterlichamen (Van den Roovaart et al. 2012).

- Toepassingen door waterschappen. Vanuit de waterschappen is het al lang de wens dat het landelijk instrumentarium beter aansluit op de beschikbare gegevens/watermodellen vanuit de verschillende 
beheersgebieden. De evaluatie en uitvoering van KRW is minder top-down dan die van EZ (evaluatie mestbeleid) en er ligt inhoudelijk veel variatie op regionaal niveau.

- Daarnaast worden resultaten van het mestmodel en de daaraan gekoppelde uitspoelings- en emissiemodellen ook gebruikt voor andere internationale rapportages dan genoemd bij EmissieRegistratie (Rijncommissie, IPCC).

\subsection{Gerelateerde Europese richtlijnen en hun onderlinge relaties}

\subsubsection{Relatie KRW met Nitraatrichtlijn en Natura 2000}

De Kaderrichtlijn Water (KRW) vereist dat chemische en ecologische condities voor grond- en oppervlaktewateren uiterlijk in 2027 op orde zijn gebracht. Om deze watercondities op orde te krijgen, wordt gewerkt met zesjaarlijkse stroomgebiedbeheerplannen (SGBP's, zie:

www.waterkwaliteitsportaal.nl), waarin doelen- en maatregelenprogramma's zijn opgenomen. In de eerste SGBP's (uitvoeringsperiode 2010-2015) zijn vooral inrichtingsmaatregelen voor oppervlaktewateren en generiek beleid voor de kwaliteit en kwantiteit van grond- en oppervlaktewateren opgenomen. Het is de bedoeling om in de tweede en derde generatie SGBP's (2016-2021, 2022-2027) verdere aanvullende maatregelen te nemen. De KRW richt zich op het bereiken van een Goede Ecologische Toestand (GET) voor natuurlijke oppervlaktewateren en een Goed Ecologisch Potentieel (GEP) voor sterk veranderende en kunstmatige oppervlaktewateren. Voor het bepalen van het bij deze doelen te voeren waterbeheer wordt op gebiedsniveau gekeken naar het gewenst grond- en oppervlaktewaterregime (GGOR). De provincies hebben de kaders voor deze GGOR-en bepaald, die vervolgens door de waterschappen zijn vastgesteld. Het Ministerie van Infrastructuur en Milieu (I\&M) is eindverantwoordelijk voor de implementatie van de KRW.

De KRW is nauw verbonden met de Habitat Richtlijn (Natura 2000) en de Nitraatrichtlijn (NR). Zo wordt in het kader van Natura 2000 gewerkt aan zesjaarlijkse beheerplannen (op dit moment lopen de $3^{\mathrm{e}}$ beheerplannen, 2014-2019) en binnen de NR gewerkt aan vierjaarlijkse actieplannen (op dit moment wordt gewerkt aan het $5^{e}$ actieprogramma, 2014-2017) (zie Figuur 1). Het Ministerie van Economische Zaken (EZ) is verantwoordelijk voor zowel Natura 2000 als voor de NR.
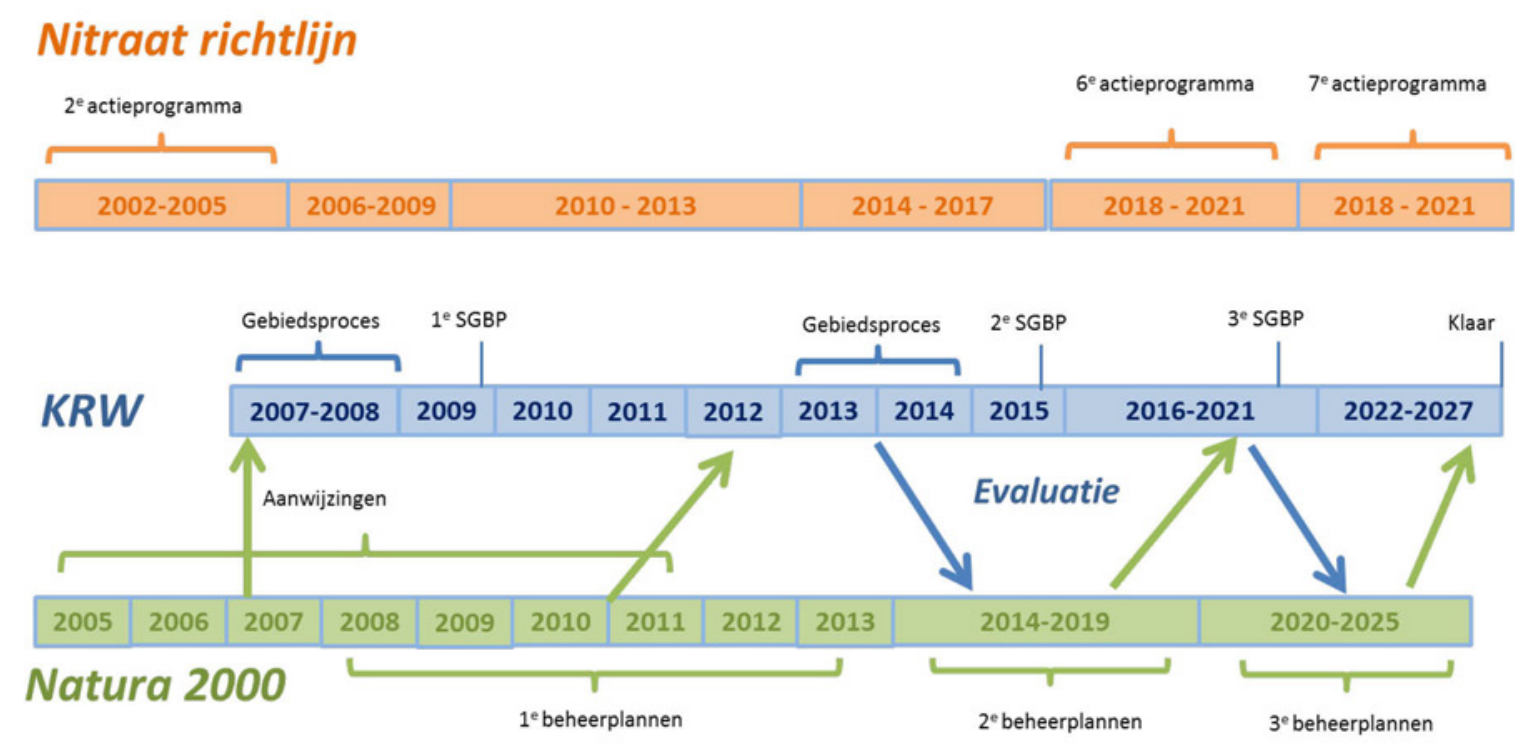

Figuur 1 Planning en proces KRW in relatie tot Natura 2000 en Nitraatrichtlijn (Bron: gebaseerd op Factsheet Natura 200 en Kaderrichtlijn Water.pdf). 


\subsubsection{Relatie mestverdeling met de PAS}

Een belangrijk aandachtspunt bij de PAS is het op gedetailleerde wijze in kaart brengen van de ammoniakemissie. Door een aantal ontwikkelingen vereist dit steeds meer maatwerk, zowel op bedrijfs- als op gebiedsniveau. Zo is het wenselijk dat de effecten van specifieke maatregelen op bedrijfsniveau, zoals voeraanpassingen en perceel-specifieke bemesting, ook daadwerkelijk worden meegenomen bij de emissie- en depositieberekeningen. Nu wordt dit maatwerk nog niet goed in de nationale emissieberekeningen - die de basis vormen voor de Aerius-berekeningen - meegenomen.

Het opnemen van maatwerk is zowel wenselijk vanuit de landbouw (i.v.m. het effect op ontwikkelruimte) als vanuit de natuur (i.v.m. instandhoudingsdoelstelling). Het gedetailleerd in kaart brengen van de emissies is niet alleen van belang bij (i) het monitoren van de effecten van gebiedsinitiatieven ten aanzien van ammoniak, maar ook bij (ii) het leggen van relaties tussen berekende en gemeten ammoniakconcentraties en (iii) ten aanzien van het beweiden en bemesten nabij een Natura 2000-gebied zonder Nb-wet vergunning.

Binnen het regionale ammoniakbeleid in Nederland wordt vnl. gebruikgemaakt van nationale generieke gegevens die in tweede instantie worden neergeschaald naar een gedetailleerde ruimtelijke resolutie. Zo wordt door de EmissieRegistratie (ER) op basis van CBS/LEI-gegevens de $\mathrm{NH}_{3}$-emissie bepaald op nationaal niveau volgens de NEMA systematiek (Van Bruggen et al. 2014).

Ten behoeve van de PAS wordt gebruikgemaakt van het systeem Aerius (Metz, 2015) om op gedetailleerde schaal $(100 \mathrm{~m} \times 100 \mathrm{~m})$ de stikstofdepositie op natuur te berekenen ten gevolge van $\mathrm{N}$ (waaronder $\mathrm{NH}_{3}$ ) emissies naar de lucht. Voor de $\mathrm{NH}_{3}$-emissie maakt Aerius gebruik van de ruimtelijke neergeschaalde nationale emissie gegevens op basis van: (i) Giab/landbouwtelling voor de $\mathrm{NH}_{3}{ }^{-}$ emissie vanuit stallen en opslagen op bedrijfsniveau en (ii) MAMBO en aanvullende geografische informatie voor de $\mathrm{NH}_{3}$-emissie op het niveau van $500 \mathrm{~m} \times 500 \mathrm{~m}$. De som van deze met MAMBO berekende $\mathrm{NH}_{3}$-emissies voor heel Nederland is gelijk aan de totale emissie berekend met NEMA. De emissies zitten 'statisch' (houdt geen rekening met veranderingen die gedurende het jaar en al of niet in een specifieke regio plaatsvinden) en qua parametrisatie voornamelijk 'generiek' (maakt slechts beperkt gebruik van bedrijfs- of regio-specifieke situatie) in Aerius. Hierdoor is de ruimtelijke resolutie van de (toedienings)emissie $(500 \mathrm{~m} \times 500 \mathrm{~m})$ niet in lijn met die van de depositie $(100 \mathrm{~m} \times 100 \mathrm{~m})$ en worden de effecten van maatregelen niet adequaat verdisconteerd in de depositieberekening. 


\section{Inventarisatie van eisen en criteria}

\subsection{Resultaten workshop}

Op 23 november 2016 is er een workshop gehouden waarbij met name deskundigen van PBL, ER, RVO, CBS, WUR, Waterschappen en Provincies betrokken waren. In Bijlage 1 is een overzicht gegeven van het programma, de deelnemers en een verslag van de workshop.

Aspecten die tijdens de workshop aan de orde zijn geweest, betroffen:

- Herkomst en actualiteit van gegevens.

- Ruimtelijke schaal en flexibiliteit voor aanpassing in verandering in ruimtelijke aggregaties, consistentie van resultaten bij gebruik voor verschillende ruimtelijke schalen.

- Flexibiliteit ten aanzien van aanpassingen en uitbreidingen.

- Doorlooptijd van vraag tot antwoord (levering).

- Kosten voor ontwikkeling, beheer en onderhoud, toepassing, overhead.

- Een model dat zowel geschikt is voor basisprognose als voor toekomstverkenningen of twee aparte modellen die onderling consistent zijn.

- Geschikt voor ex-anteanalyses en toekomstverkenningen.

- Afstemming met andere partijen en op modellen waarvan invoer wordt gebruikt (RVO, CBS, CPB, etc.).

- Afstemming met andere partijen die belang hebben bij mestgegevens (EmissieRegistratie).

- Mate waarin de wetenschappelijk kwaliteit is geborgd.

- Operationaliteit en continuïteit zijn organisatorisch geborgd.

- Het zelf toepassen, bijv. via een webapplicatie, van de mestverdelingsmodule door derden.

De volgende wensen en knelpunten t.a.v. mestverdelingsmodule werden tijdens de workshop geïnventariseerd:

\section{$E Z / I \& M:$}

De ministeries van EZ en I\&M vragen om een mestverdelingsmodule die voldoet aan de volgende kwalificaties:

- Goed, actueel, realistisch en die de huidige situatie zo goed mogelijk beschrijft.

- Flexibel, te allen tijden operationeel, snel te actualiseren met geringe inspanning, met weglating van niet-essentiële details.

- Vormt een consistent geheel met de overige modellen/methodieken uit de gehele "mestketen" van productie $\mathrm{t} / \mathrm{m}$ emissies naar lucht (NEMA, ER) en water (STONE, ER).

- Een ruimtelijk detail dat afhankelijk is van de beoogde vraag.

- Integratie met beleidssporen ( $3^{\mathrm{e}}$ stroomgebiedsbeheerplannen KRW (SGPB, 2022-2027), $6^{\mathrm{e}}$ Nitraat Actieprogramma (2018-2021) ( $7^{\mathrm{e}}$ start tegelijk met $\left.3^{\mathrm{e}} \mathrm{SGBP}\right), 3^{\mathrm{e}}$ beheersplannen Natura 2000 (2020-2015)) moet efficiënter en effectiever worden (zie paragraaf 2.2.1).

- Eenduidige aansturing is noodzakelijk om (i) kosten te beperken en (ii) consistentie te vergroten.

PBL:

Huidig modelleninstrumentarium voor nutriëntenbelasting oppervlaktewater sluit niet goed aan op de KRW verkenner (te gebruiken voord de KRW evaluatie 2018):

- Weinig flexibel, vaste plots die niet aansluiten op KRW-waterlichamen.

- Geen herkenning in de regio.

- Verouderde hydrologie.

Het nieuw te ontwikkelen Nationaal Nutriënten Model (NNM, betreft onderdeel van het Nationaal Watermodel) moet deze knelpunten het hoofd bieden, waarbij het t.a.v. van de mestverdelingsmodule gaat om:

- Ex post (basisprognose): het zo goed mogelijk beschrijven van de werkelijke situatie. 
- Ex ante (toekomstverkenningen): een flexibel systeem dat minder eisen stelt ten aanzien van details.

Beide systemen hoeven niet noodzakelijkerwijs in één model geïntegreerd te worden, maar dienen wel volledig consistent te zijn. Wens is om het NNM in te zetten voor de voor KRW Evaluatie 2018. Dit betekent dat het NNM beging 2018 operationeel moet zijn voor een landelijke toepassingen. Na 2018 kan dan gewerkt worden aan een nadere detaillering t.b.v. regionale toepassingen.

Eisen vanuit de werkgroep rondom het NNM t.a.v. mestverdelingsmodules:

- Informatie over gehalten aan organische stof, $\mathrm{N}$-mineraal, $\mathrm{N}$-effectief, $\mathrm{N}$-organisch, P-mineraal en P-organisch van de verschillende mestsoorten.

- Afstemming indeling gewassen/vruchtwisseling bij berekening van mestverdeling en NNM is nodig. Rekening houden met opbrengst-afhankelijk bemesten (equivalente maatregel).

- Behoefte aan een historische en toekomstige consistente tijdreeks (focus op een specifiek jaar: risico's i.v.m. toevallige effecten).

- Zo mogelijk een verdeling binnen het jaar om rekening te houden met praktijkomstandigheden en met scenario's waarin effecten van toepassingsperioden en precisiebemesting worden berekend.

- Naast dierlijke mest ook aanvoer van overige organische mestproducten (deze worden in MAMBO/STONE niet meegenomen).

- Mogelijkheden om opties voor overbenutting van gebruiksruimte in te stellen.

- Consistentie in aannamen t.a.v. P-status (Pw/PAL ivm P-gebruiksnorm) en een realistische schatting van de verwachte ontwikkeling van de fosfaattoestand als gevolg van toekomstige mestgiften en P-overschotten, waarbij rekening gehouden wordt met de wettelijke gebruiksvoorschriften.

- Consistentie in gehanteerde kunstmesthoeveelheden. Er circuleren ruwweg twee varianten: BIN en kunstmeststatistiek van Wageningen Economic Research (WECR). Hierbij betreft de BIN-variant de ruimtelijke differentiatie van de landelijke hoeveelheid, maar deze tellen niet op tot de totalen van de kunstmeststatistiek. Op dit moment word er in de Taakgroep Landbouw ernstig getwijfeld aan de kwaliteit van de kunstmeststatistiek. Er wordt aan gedacht over te stappen op BIN.

Mest- en landbouwdata-CBS:

- De CBS meststatistieken worden gebruikt t.bv. StatLine \& Compendium Leefomgeving, CBS RIVM/Emissieregistratie (incl. NEMA) en werk voor derden (bijv. Nitraatrichtlijnrapportage \& Evaluatie Meststoffenwet).

- Het ontsluiten van RVO vervoerbewijzen was in eerste instantie een hele toer geweest, maar is nu goed ingebed en geautomatiseerd. Dit geldt in zijn algemeenheid voor nieuwe informatiebronnen. Het voor de eerste keer ontsluiten is tijdrovend, maar als dat eenmaal is vastgelegd, gaat het actualiseren snel.

- Het CBS genereert zelf geen data en is wat kwaliteit betreft afhankelijk van de kwaliteit van de aangeleverde data. Zo zijn de kunstmestcijfers afkomstig van WEcR (LEI), maar zijn wel twee versies in omloop (zie hierboven). Wel voert het CBS zelf correcties uit in de aangeleverde landbouwtellingsgegevens.

\section{Mest- en landbouwdata-ER:}

- ER rapporteert jaarlijks, maar eens per 3-4 jaar worden de (mesttoedienings)cijfers ruimtelijk verdeeld.

- Mesttoediening betreft de meest onzekere factor bij het (ruimtelijk gedifferentieerd) bepalen van de stikstofdepositie. Verder is het omgaan met trendbreuken een lastig punt.

- MAMBO-STONE wordt als een kostbaar instrumentarium ervaren, nadat door beëindigen van mestmarktrapportages updates alleen op ad-hocbasis worden uitgevoerd. Door de hoge kosten wordt MAMBO niet jaarlijks geüpdatet.

- Probleem is dat er geen afspraken bestaan over verdeling van kosten en lange termijn zekerheid voor inzet MAMBO. Het gevolg hiervan is dat de kosten niet evenwichtig verdeeld worden onder de gebruikers. Nu komen alle kosten voor een update ten laste van degene die het eerst met een opdracht komt. Zo kan het voorkomen dat ER opdraait voor alle kosten, terwijl overige gebruikers tegen relatief lage kosten aanvullende vragen kunnen stellen. Wanneer gekozen worden voor een update om de twee jaar, waarbij de ene keer de kosten ten laste van ER en andere keer ten laste van EMW komen, krijg je al een evenwichtigere verdeling. 


\section{Wensen waterschappen en provincies:}

- Jaarlijks een ruimtelijk expliciet bestand met mesttoediening op perceelniveau. Zowel voor de huidige situatie als toekomstscenario's.

- Aansluiting bij de praktijk. Zo is er bij Waterschappen en overige regionale instanties veel gebiedsinformatie beschikbaar die beter benut zou kunnen worden.

- Mest is breder dan dierlijke mest; kunstmest en overige organische producten zijn ook van groot belang.

\subsubsection{Inventarisatie van eisen en criteria}

Ten behoeve van de Inventarisatie van eisen en criteria zijn de volgende vragen voorgelegd aan de workshopdeelnemers. Wat zijn de eisen en criteria ten aanzien van:

- Het schaalniveau

- Basisprognose (ex post) en Toekomstverkenningen (ex ante)

- Flexibiliteit (t.a.v. te verwachten (nieuwe) vragen)

- Consistentie/afstemming (met overige beleidssporen)

- Operationele aspecten (Ontwikkeltijd, tijd/kosten reguliere en ad-hoc toepassingen, bestuurlijke aspecten)

In onderstaande tabel zijn de belangrijkste aspecten samengevat.

Tabel 2 Samenvattend overzicht van de huidige en gewenste situatie met betrekking tot het modelleren van de mestverdeling zoals aangegeven door de deelnemers van de workshop.

\begin{tabular}{|c|c|c|}
\hline Aspect & Huidige situatie & Gewenste situatie ${ }^{1)}$ \\
\hline $\begin{array}{l}\text { Schaalniveau } \\
\text { - Ruimtelijke schaal: } \\
\text { - Temporele schaal: }\end{array}$ & $\begin{array}{l}\text { MAMBO (twee stappen): } \\
\text { 1. Per gemeente, per gewasgroep, per } \\
\text { bodemtype } \\
\text { 2. Neerschalen naar Stoneplot (gewas, } \\
\text { bodemtype, hydrologie) } \\
\text { 1 jaar }\end{array}$ & $\begin{array}{l}\text { Minimaal waterlichamen en bijbehorende } \\
\text { stroomgebieden (ca. } 800 \text { gebieden); maar } \\
\text { daarnaast ook de mogelijkheid om in te zoomen } \\
\text { naar herkenbare lagere eenheden zoals polders, } \\
\text { KRW-lichamen en percelen, waarbij tevens } \\
\text { sprake is van een gewasspecifieke indeling. } \\
\text { Kwartalen/seizoenen }\end{array}$ \\
\hline $\begin{array}{l}\text { Scenario's } \\
\text { - Basisprognose } \\
\text { (ex post): }\end{array}$ & Op basis van CBS, RVO en BIN data & $\begin{array}{l}\text { Met actualisatie van onderliggende gegevens } \\
\text { Tijdreeksen, eventueel steekjaren met de } \\
\text { mogelijkheid tot interpoleren }\end{array}$ \\
\hline
\end{tabular}

\footnotetext{
2 Nationale Energie verkenning De NEV brengt jaarlijks de stand van zaken rondom de energiehuishouding in Nederland in kaart.

3 Toekomstverkenning 'Welvaart en Leefomgeving'.
} 
Flexibiliteit

- Ruimtelijke aggregaties:

Gering: ruimtelijke aggregatie is gefixeerd.

- Processen

Gering: liggen in principe vast

- Temporele schaal
Flexibiliteit nodig: landgebruiksverandering, opsplitsing in kleinere arealen. Dit vloeit voort uit de toekomstscenario's en de (model)opties die daarvoor nodig zijn.

Flexibiliteit nodig: als hierboven.

Flexibiliteit is nodig; model moet hoger geaggregeerde invoer consistent kunnen desaggregeren en vice versa.

NNM: vraagt slechts om globale ex-anteresultaten, maar de mestverdeling dient wel op plotniveau (ca. 20 000) te worden aangeleverd. Waterschappen: vragen om meer detail.

Consistentie

- Ruimtelijke schaal Consistentie bij gebruik voor verschillende

- Organisaties/modell Met andere partijen en op modellen waarvan en/data invoer wordt gebruikt (RVO, CBS, CPB, etc.)

\section{Idem} met LGN; CBS gecorrigeerde landbouwtelling,
Bassiregistratie gewaspercelen (BRP), aangevuld mesttransporten (RVO), NEMA en AERIUS

Afstemming nodig tussen ER, PAS, NEMA, Monitoring mestmarkt en Stone/NNM WUM-NEMA), NHI-wq (basis MAMBO) en monitoring mestmarkt (gebaseerd op forfaitaire excreties)

- Basisprognose en Beide zijn op elkaar afgestemd

Idem toekomstverkenningen

Borging

- Wetenschappelijk Borging via documentatie en rapporten kwaliteit

- Operationele kwaliteit

Versiebeheer van modelcodes en continuïteit zijn organisatorisch geborgd Sinds 2015 geen borging vanwege gebrek aan budget voor beheer en onderhoud

Operationaliteit

- Tijd:

Doorlooptijd van vraag tot antwoord (beantwoorden van ad-hoc- en/of reguliere vragen)

- Kosten: Kosten voor ontwikkeling

Kosten voor beheer, onderhoud (overhead) Kosten voor toepassing

- kosten zitten vooral in de data en minder in het rekenen

Beschikbaarheid

- Data en Vrij divers en niet altijd consistent modelresultaten:

- Model: Model is niet beschikbaar voor derden

\footnotetext{
1) Met name aangedragen door PBL, I\&M en EZ.
}

Zorg voor goede en continue borging en afstemming

Volgens eisen ER; kennis over input ook goed borgen
Uiterlijk medio 2018 operationeel

Ex-antevragen: moeten binnen een week beantwoord kunnen worden; basisprognose en reguliere vragen mogen langer duren.

Laten we eerst zien wat er nodig zou zijn om de vragen te kunnen beantwoorden...

Idem

Wat in elk geval nodig is, is een gestructureerd overzicht van mogelijke input en mogelijke actualisatie met de bijbehorende kosten.

Duidelijke documentatie nodig welke data het model in- en uitgaan en hoe deze te verkrijgen

Waterschappen: inzicht in bodembelasting vanuit mest, als grids/kaarten zodat ze die kunnen gebruiken in hun watersysteemanalyses.

Eventueel de mogelijkheid om een "lichte versie" zelf te kunnen toepassen voor exantevragen.

\section{Prioritering:}

- Maak onderscheid in wat wenselijk en mogelijk is in periode voor 2018 en wat in de periode na 2018. Focus voor de periode voor 2018 op de gewenste situatie wat ruimtelijke schaal betreft, dwz: waterlichamen + bijbehorende stroomgebieden (ca. 800 gebieden). 


\section{Knelpunten:}

Tijdens de workshop werden de volgende knelpunten gesignaleerd:

- Er is sprake van een schaalverschil tussen de Meststoffenwet en de KRW. De Meststoffenwet werkt op het niveau van grondsoortenregio's, terwijl de KRW per waterlichaam werkt en de eigenlijke maatregelen op bedrijfsniveau uitgevoerd worden. Dit vraagt om bijzondere aandacht bij de implementatie van maatregelen. Daarnaast hebben de Waterschappen ook wensen/ doelen voor overig, niet KRW, water om daar ook waterkwaliteit te verbeteren. Het grootste deel van het watersysteem in Nederland is niet KRW.

- Het opzetten van een heel nieuw model is niet realiseerbaar binnen beschikbare tijd (d.w.z. in 2018 operationeel).

- Creëer een platform die de ontwikkeling aanstuurt (dit ontbreekt nu), bijv. Stuurgroep met EZ (RVO), I\&M, RIVM, PBL, Waterschappen, Provincies.

- Wie neemt de verantwoordelijk om de resultaten verder vorm te geven? Wie gaat de besluiten nemen?

- Hoe om te gaan met databeschikbaarheid (privacy, eigendom)?

Epiloog:

Een praktisch aandachtspunt is de aanwezigheid van diverse beleidsmatige ruimtelijke eenheden, die op elkaar afgestemd dienen te worden. Zo is de doelschaal sterk afhankelijk van instelling en ex post versus ex ante:

- PBL voornamelijk landelijk (en de ex ante slechts globaal).

- ER voornamelijk landelijk; maar ook regionaal in relatie tot stikstofdepositie.

- Provincies: regionaal.

- Waterschappen: op polderniveau/KRW Waterlichamen (zowel voor ex post als ex ante).

Van belang is dat de Stuurgroep ER en stuurgroep NHI Initiatief neemt. De wijze waarop dit vorm moet krijgen, dient nog uitgewerkt te worden.

Verder is het zaak om de huidige situatie, met name qua datastromen, goed in kaart te brengen en op basis daarvan tot een advies te komen hoe de bestaande en eventueel nieuw toe te voegen datastromen (beter) te stroomlijnen. Zorg voor goede en continue borging en afstemming en regel taken bevoegdheden en verantwoordelijkheden. 


\section{Inventarisatie van huidige mestverdelingsmodellen en/of methodieken}

\subsection{MAMBO}

\subsubsection{Modelbeschrijving}

MAMBO is een modelraamwerk om analyses uit te voeren rondom de productie, toediening en transport van dierlijke mest Daarnaast berekent MAMBO de verdeling van kunstmest. In MAMBO zijn microeconomische simulatiemodellen voor het vaststellen van boerenbeslissingen op bedrijfsniveau gekoppeld aan een ruimtelijk evenwichtsmodel dat de verdeling van mest in Nederland tussen overschotgebieden en gebieden met plaatsingsruimte simuleert. MAMBO rekent op diertypeniveau per bedrijf, en op gewasniveau per bedrijf voor bedrijfseigen mest. De verdeling van de bedrijfsvreemde mest, het mesttransport, wordt middels LP berekend op het niveau van 31 mestgebieden (regio's). De uitkomsten van deze simulaties (in termen van mest- en mineralengebruik en emissies) op bedrijfs- en geaggregeerd niveau worden vertaald naar het gemeenteniveau per diergroep, gewasgroep en grondsoortcombinatie voor het samenvoegen van alle relevante informatie. Daarbij wordt het gedrag van boeren gesimuleerd met betrekking tot economische keuzes voor mesttoediening en afvoer van geproduceerde mest. Naast de keuzes op bedrijfsniveau simuleert MAMBO op basis van economische principes ook de werking van de mestmarkt en de verdeling van mest tussen overschot- en tekortgebieden. Tevens wordt inzicht geboden in de mestmarkt en de daarmee samenhangende mineralenstromen.

MAMBO maakt gebruik van de volgende uitgebreide databestanden:

1. de recentste gegevens van de structuur van de landbouw afkomstig uit onder andere de landbouwtelling (CBS), de bodemstatistiek (CBS) en de BRP (Basisregistratiepercelen);

2. berekeningen uit het Bedrijven Informatienet (BIN) van het WEcR;

3. monitoringsgegevens t.b.v. beleid (RVO);

4. technische coëfficiënten (PBL,WUM, werkgroep NEMA, PPO) voor diverse soorten emissies.

Op basis van de berekende mineralenstromen berekent MAMBO de mineralenbelasting van de bodem afkomstig van het gebruik van mest en kunstmest, en biedt het de mogelijkheden om broeikasgasemissies uit de mesttoediening, de stal, de mestopslag en de bodem mee te nemen. Zo houdt MAMBO een boekhouding bij van mest en mineralen met de daaraan gekoppelde directe emissies naar lucht, bodem en water. Hierbij gaat het om de emissie van $\mathrm{NH}_{3}, \mathrm{~N}_{2} \mathrm{O}, \mathrm{NO}_{x}$ en $\mathrm{N}_{2}$. Daarnaast kan MAMBO ook de emissie van methaan en fijn stof berekenen (De Koeijer et al. 2012; Kruseman et al. 2013; De Koeijer et al. 2014).

Voor het kunstmestgebruik zijn de gegevens gebruikt van de LEIjaarstatistiek van het kunstmestgebruik en het Bedrijveninformatienet (www.agrimatie.nl). Voor de verdeling van de in Nederland afgezette dierlijke mest zijn afzetgegevens van RVO en gegevens uit het Bedrijveninformatienet de basis. Verder wordt gebruikgemaakt van de wettelijk vastgelegde coëfficiënten uit de mestwetgeving, zoals productieforfaits, N-correctie, gebruiksnormen en werking coëfficiënten (https://mijn.rvo.nl/mest-tabellen-en-normen).

MAMBO werkt in twee stappen voor de verdeling van bedrijfsvreemde mest. Eerst wordt de mest verdeeld op het niveau van de 31 mestgebieden en wordt vertaald naar het gemeenteniveau per diergroep, gewasgroep, grondsoortcombinatie en fosfaattoestand van de bodem voor het samenvoegen van alle relevante informatie. Vervolgens wordt het neergeschaald naar een $500 \mathrm{~m} \times$ $500 \mathrm{~m}$ resolutie. Dit wordt gedaan ten behoeve van gebruik door de ER en de modellen:

- Stone/Evaluatie mestbeleid

- AERIUS/PAS

- OPS 
Om op basis van de berekende bemesting de bodembelasting in beeld te brengen, is de bemesting uitgesplitst in de omvang van de emissie naar de lucht en de daadwerkelijke belasting van de bodem. Voor de berekening zijn hoofd- en nevenvestigingen apart onderscheiden, zodat de ruimtelijk specifieke emissie uit stallen en mestopslagen zo nauwkeurig mogelijk kon worden berekend. De locatie en de verdeling van dieraantallen over de hoofd- en nevenvestigingen zijn afkomstig van het GIAB-model van WEnR. Bij de berekening is geen rekening gehouden met de verdeling van het areaal cultuurgrond per hoofd- en nevenvestiging. Het areaal cultuurgrond is volledig toegewezen aan de hoofdvestiging. Dit heeft tot gevolg dat de ruimtelijke distributie van bedrijfseigen en bedrijfsvreemde mest afwijkt van de praktijk.

Voor het bepalen van de regionale bemesting, de ammoniakemissie en de daaruit volgende bodembelasting worden in MAMBO vijf processen onderscheiden (Kruseman et al. 2013):

1. de productie van mest en mineralen door dieren (mineralenproductie);

2. de plaatsingsruimte voor het gebruik van mest en mineralen (plaatsingsruimte);

3. het saldo van de mest- en mineralenproductie en plaatsingsruimte (mineralenoverschot);

4. de distributie en verwerking van mest en mineralen (mesttransport);

5. de mineraalbelasting van de bodem (bodembelasting).

In MAMBO wordt onderscheid gemaakt in de mineralenstromen volgens:

- De normeringen in de mestwetgeving, het zogenaamde wettelijke spoor. De mineralenproductie van graasdieren wordt daarbij berekend met de productieforfaits uit de mestwetgeving. De mineralenproductie van hokdieren wordt daarbij berekend door de WUM-excreties te verminderen met de $\mathrm{N}$-correcties.

- Het tweede spoor, het zogenaamde 'werkelijke spoor'. Daarbij wordt de mineralenproductie berekend door de WUM-excreties te verminderen met de gasvormige verliezen zoals die door de NEMA-werkgroep van de CDM zijn vastgesteld (Velthof et al. 2009a).

Voor de berekening van de bodembelasting wordt gebruikgemaakt van het tweede, spoor het zogenaamde 'werkelijke spoor'.

Op basis van de gemeentekaart, de bodemstatistiek van het CBS en de BRP (Basisregistratie percelen, zijn de ammoniakemissies ruimtelijk verdeeld over gridcellen van $500 \mathrm{~m} \times 500 \mathrm{~m}$.

\subsubsection{Modelinput}

Elk jaar dient het model voor monitoring eenmalig gevoed of aangepast te worden met de actuele gegevens van het betreffende jaar. Dat zijn:

1. technische gegevens

2. normatieve gegevens (excretie per dier, emissiefactoren, landbouwkundige werkingscoëfficiënten

3. verdeling weide- en stalmest, kunstmestgebruik, dierlijk mestgebruik

4. wettelijk vastgelegde coëfficiënten

5. activiteitendata:

- dieraantallen (Landbouwtelling)

- huisvesting (Landbouwtelling, niet jaarlijks)

- mestopslag buiten de stal (Landbouwtelling, niet jaarlijks)

- locatie van stallen (GIAB, optioneel)

- arealen (Landbouwtelling)

- toedieningstechniek (Landbouwtelling, niet jaarlijks)

- afzet dierlijke mest buiten de landbouw (RVO)

- verwerking van dierlijke mest (CBS)

De technische en normatieve gegevens voor het berekenen van de ammoniakemissie, zoals de emissiefactoren, zijn afkomstig uit NEMA (Van Bruggen et al. 2014). De excreties en de verdeling van de mest over weide- en stalmest zijn gebaseerd op de WUM-cijfers van het betreffende jaar

(Van Bruggen et al. 2014). 
Doordat voor de meeste opdrachten de informatie op bedrijfsniveau aan het model wordt aangeboden, is de kwaliteit hiervan erg goed. Elk jaar is er een investering nodig van 40-50 mensdagen (op basis van EMW 2006) om al die gegevens op bedrijfsniveau voor het model beschikbaar te maken (zie ook onderhoud). Wanneer die investering eenmaal heeft plaatsgevonden, vergt een modelrun op basis van die investering enkele uren tot maximaal 1 dag.

\subsubsection{Modeloutput}

MAMBO rekent op basis van economische principes zowel op bedrijfs- als op regioniveau. Het meest gedetailleerde niveau waarop MAMBO output levert, is op grid-niveau (van $500 \mathrm{~m} \times 500 \mathrm{~m}$ ). Afhankelijk van de opdrachtgever kan de output vervolgens op elk hoger schaalniveau (gemeentes, stroomgebieden, provincies, etc.) tot het Nationaalniveau worden opgeleverd. De MAMBO uitvoer wordt aangeleverd voor 18 gewasgroepen uit de BRP en 6 soorten weidmest en 10 soorten stalmest (conform de ER).

De output bestaat uit emissies, excreties, bemesting, mestscheidingsproducten, mestafzetstromen en de mestafzetkosten op gemeenteniveau. De gasvormige emissie worden in een nabewerking ruimtelijk verdeeld over gridcellen van $500 \mathrm{~m} \times 500 \mathrm{~m}$. Naast de standaardoutput levert MAMBO ook de emissie van fijn stof, de bodembelasting met zware metalen, dikke en dunnen mestfractie per mestsoort, de mestafzetkosten en de mestafzetstromen.

\subsubsection{Scenario's/maatregelen}

MAMBO kan de effecten op emissies, excreties, bemesting, mestafzetstromen en mestafzetkosten van zowel EU-beleidsmaatregelen als Nederlands mestbeleid en van ammoniakbeleid doorrekenen. Het betreft zowel ex-ante- als ex-postevaluaties.

Naast de standaardmaatregelen die vooral milieutechnisch van aard zijn, zijn ook meer economisch getinte maatregelen in de tabel hieronder opgenomen. Deze maatregelen grijpen direct aan op de mestmarkt. Het gaat om maatregelen als: verplichte mestverwerking en effecten van prijsveranderingen van niet-verplichte mestverwerking, van kunstmest en van dierlijke mest.

\subsubsection{Afstemming en operationele aspecten}

\section{Relatie met andere modellen}

MAMBO levert input aan de volgende modellen en monitoringssystemen:

- NEMA (CBS): Voor de verdeling van de afzet van de mest in Nederland over landbouw, niet landbouw en grasland en bouwland worden elk jaar MAMBO gegevens aan NEMA geleverd. Voor het kunnen neerschalen van de nationale data levert MAMBO de regionale verhoudingsgetallen op, op basis van de locatie-specifieke berekeningen van de ammoniakemissie.

- OPS (RIVM/WECR): Met de locatie-specifieke data van ammoniakemissies kan met OPS de locatiespecifieke depositie worden berekend.

- STONE (Alterra): met de locatie en gewasspecifiek berekende bodembelastingen met mest van stikstof en fosfaat kan STONE de effecten op de uit- en afspoeling en nitraatconcentraties berekenen.

- DRAM (WEcR): Voor studies als: De agrarische sector in Nederland naar 2020 (Silvis et al. 2009) worden resultaten tussen MAMBO en DRAM uitgewisseld en met beide modellen worden berekeningen uitgevoerd.

\section{Kwaliteitsborging}

De kwaliteit van MAMBO wordt continu beoordeeld. Dit gebeurt intern bij het WEcR door middel van modellen audits en extern door bijvoorbeeld WOT Natuur \& Milieu met modellen statuskwaliteit A en AA. Door te voldoen aan kwaliteitskeurmerken kunnen gebruikers van MAMBO-uitkomsten er beter van op aan dat de modelresultaten ook kloppen binnen de aangegeven betrouwbaarheidsgrenzen.

In 2010 is de kwaliteitsstatus A van de WOT-Natuur en Milieu verkregen. Sinds 2008 zijn de WEcR modellen en daarmee ook MAMBO opgenomen in het kwaliteitshandboek van het WECR. 
Modelkwaliteit is daarmee een expliciet thema geworden in de kwaliteitsaudit en de toekenning van het ISO kwaliteitscertificaat. Dit schept verplichtingen rond de kwaliteit van modellen en de inspanningen om de kwaliteit op niveau te brengen en in stand te houden. In juni 2010 en 2013 heeft er een vervolgaudit plaatsgevonden.

Voor de kwaliteitsborging is MAMBO 2.0 ondergebracht onder een modelarchitectuur ontwikkeld op het WECR dat kwaliteitsborging ten doel heeft (Quality Based generic GAMS Modelling: QBGM). Door de toepassing van QBGM wordt bij de aanpassing van het model naar een andere versie automatisch een aantal kwaliteitscontroles uitgevoerd waarbij expliciet aandacht wordt besteed aan de ontwikkeling en vervolgens het testen van de rekenregels. Hierbij is tevens voorzien in gevoeligheidsanalyses en het accorderen van de nieuwe modelversie. Daarbij worden de stuurvariabelen op validiteit gecontroleerd. Deze kwaliteitsborging heeft betrekking op modelcodeaanpassingen die het gevolg zijn van veranderende uitgangspunten, regels rond mest- en mineralenwetgeving en ontwikkelingen zoals mestbe- en verwerking.

\section{Zelfevaluatie}

De uitkomsten van MAMBO zijn cruciaal voor het mestbeleid. Op basis van MAMBO-resultaten wordt nagegaan in hoeverre er knelpunten in de uitvoering van het beleid optreden. De resultaten geven tevens inzicht in de aard van benodigd aanvullend beleid, zoals de voorstellen rondom verplichte mestverwerking. Ook kan op basis van MAMBO-berekeningen (t.b.v. Stone) inzicht worden verkregen in de waterkwaliteit die noodzakelijk is voor de invulling van het Nitraat Actie Programma.

Voor het in beeld brengen van grote verschuivingen op de mestmarkt zoals die zullen optreden bij de voorstellen rondom mestverwerking en het wegvallen van dierrechten en de melkquotering is MAMBO essentieel. MAMBO kan door koppeling van de mestprijzen met het aanbod en de vraag naar mest en door de inbreng van mestscheiding aangeven hoe de mineralenstromen zich zullen aanpassen.

Op basis van economische drijfveren geeft MAMBO de mineralenstromen op de mestmarkt, de emissies naar de lucht voor Nederland en de bodembelasting weer. Hierdoor is het model zeer geschikt voor scenariostudies. Met de in het model opgenomen beslisregels t.a.v. de mesttoediening van eigen dierlijke mest en de afzet van mest naar de mestmarkt op basis van minimalisatie van de mestafzetkosten kan het model goed weergeven hoeveel mest er al dan niet via mestscheiding op de markt wordt afgezet. Met het transportmodel op basis van minimalisatie van de transportkosten en de acceptatiegraden van ondernemers voor vreemde mest die afhangen van de regio, het gewas en de prijsverhouding mest/kunstmest kunnen de bestemmingen van de mest berekend worden. Daarmee geeft het model niet alleen input voor berekeningen t.a.v. de mestmarkt, maar ook t.a.v. waterkwaliteit, luchtkwaliteit, natuurkwaliteit, resource use efficiency en businesscases voor mestverwerking.

Door de modulaire opbouw van MAMBO en de strikte scheiding van modelcode en invoerdata zijn emissies van andere stoffen en gassen (bijvoorbeeld $\mathrm{CO}_{2}$ ) eenvoudig mee te nemen. Bovendien kan MAMBO met uiteenlopende classificaties van landgebruiksvormen en gewassen (bijv. verschillende aardappelrassen) alsmede indelingen van landbouwhuisdieren rekenen.

Gezien de aard van de beschikbare input data is het laagste niveau waarop MAMBO betrouwbaar de emissie naar de lucht berekend $500 \mathrm{~m}$ bij $500 \mathrm{~m}$.

Tot op heden is er nog geen financiële ruimte gevonden om de arealen naar hoofd- en nevenvestigingen te implementeren om zo de ruimtelijke verdeling van de uitrij- en weide-emissies te verbeteren. Door implementatie van hoofd- en nevenvestigingen zal met name de kwaliteit van de geografisch gedetailleerde resultaten voor met name de ER, GDN/GCN en voor Stone (t.b.v. de EMW en de KRW) verbeteren. Ook voor het berekenen van de ammoniakdepositie in het kader van de PAS kan dit van grote toegevoegde waarde zijn. 


\section{$4.2 \quad$ INITIATOR}

\subsubsection{Modelbeschrijving}

INITIATOR (Integrated Nitrogen Impact Assessment Tool on a Regional Scale) is een relatief eenvoudig en flexibel model dat alle belangrijke stikstof $(N)$ - en fosfaat $(P)$-fluxen op regionale schaal berekent, waaronder de toevoer van $\mathrm{N}$ en $\mathrm{P}$ in de vorm van kunstmest, dierlijke mest en depositie en daarnaast nog $\mathrm{N}$-binding, $\mathrm{N}$ - en $\mathrm{P}$-opname door het gewas, emissie van ammoniak $\left(\mathrm{NH}_{3}\right)$, lachgas $\left(\mathrm{N}_{2} \mathrm{O}\right)$ en stikstofoxiden $\left(\mathrm{NO}_{x}\right)$ naar de atmosfeer en uit- en afspoeling van nitraat, ammonium en fosfaat naar grond- en oppervlaktewater. Daarnaast berekent het model ook de emissies van de broeikasgassen methaan, de verandering in de voorraad aan bodemkoolstof en de bijbehorende emissie of vastlegging van $\mathrm{CO}_{2}$ uit bodems en de accumulatie en uitspoeling van basen (verzuring) en zware metalen (lood, cadmium, koper en zink). Voor een uitgebreide beschrijving van INITIATOR wordt verwezen naar De Vries et al. (2003) en Kros et al. (2011).

De $\mathrm{N}$ - en P-excretie wordt berekend door een vermenigvuldiging van de verschillende categorieën dieren met excretiefactoren. De stal- en opslagemissies van $\mathrm{NH}_{3}, \mathrm{~N}_{2} \mathrm{O}, \mathrm{NO}_{x}$ en $\mathrm{N}_{2}$ worden berekend door een vermenigvuldiging $\mathrm{N}$ - excretie met $\mathrm{N}$-emissiefracties voor de verschillende categorieën dieren en staltypen. Een mestverdelingsmodule berekent het transport van dierlijke mest op gemeenteniveau en de toevoer van mest en kunstmest naar de bodem. Een bodemmodule berekent vervolgens de bodememissies van $\mathrm{NH}_{3}, \mathrm{NO}_{x}$ en $\mathrm{N}_{2} \mathrm{O}$. De $\mathrm{NH}_{3}$-emissie uit stallen en opslagen en vanuit de bodem vormt de input van het atmosferisch transport model OPS voor de berekening van de $\mathrm{N}$-depositie op zowel landbouwgronden als Natura 2000-gebieden.

Behalve de mestverdeling en de emissies naar de atmosfeer heeft INITIATOR ook functionaliteiten voor de berekeningen van uit- en afspoeling van $\mathrm{N}$ en P. Deze zijn niet relevant in het kader van deze scoping study.

Het model maakt gebruik van gedetailleerde ruimtelijke gegevens die grotendeels afkomstig zijn uit beschikbare nationale GIS-datasets zoals de geografisch expliciete landbouwtellinggegevens, met het aantal dieren per bedrijf (GIAB-plus; Gies et al. 2015). In het Geografisch Informatiesysteem Agrarische Bedrijven (GIAB) is informatie over verschillende grondgebruiksfuncties een belangrijke basis om effecten van beleidsmaatregelen te analyseren of om nieuwe ontwerpen te maken. Hierin zijn gegevens opgenomen van landbouwbedrijven in Nederland die meedoen aan de jaarlijkse landbouwtelling van het CBS en RVO. De gegevens zijn gekoppeld aan de locatie van de hoofdvestiging van het landbouwbedrijf. Het bestand wordt onder andere gebruikt bij onderzoek naar dierziekten, landbouwstructuur-analyses, effecten van het Gemeenschappelijk Landbouwbeleid, en bij onderzoek naar emissies van geur, ammoniak en fijn stof. Voor sommige jaren zijn ook gegevens van de Gezondheidsdienst voor Dieren toegevoegd aan het GIAB. Belangrijke variabelen zijn: het bedrijfstype, de bedrijfsomvang, arealen per gewas en aantallen per diergroep. Vanaf 2011 is ook de verdeling van dieren over de nevenvestigingen en de ligging daarvan in beeld gebracht. Door deze koppeling zijn we in staat om op een hoge ruimtelijke resolutie de $\mathrm{N}$ - en $\mathrm{P}$-excretie, stal- en opslagemissies, mest- en kunstmestverdeling, bodememissie, uit- en afspoeling en $\mathrm{N}$-depositie te berekenen.

Naast INITIATOR wordt bij WEnR gebruik gemaakt van het model MITERRA (Velthof et al., 2009b; Lesschen et al., 2011). Dit model heeft een vergelijkbare opzet als het model INITIATOR, maar er zijn ook verschillen. Zo werkt de Nederlandse versie het model MITERRA-NL met een ruimtelijke resolutie van het postcode 4-niveau en bevat het diverse vormen van mestverwerking. In Bijlage 2 wordt een beknopt overzicht gegeven van de verschillen en overeenkomsten tussen beide modellen. In deze beschrijving wordt verder alleen ingegaan op het model INITIATOR.

\subsubsection{Beknopte beschrijving van mestverdelingsmodule}

De invoer van de module betreft de dierlijke mestproductie op basis van de dieraantallen in GIAB-plus en de corresponderende de excretie per dier. Waarbij voor $\mathrm{N}$ reeds rekening is gehouden met de gasvormige $\mathrm{N}$-emissies. Voor in totaal 42 diersoorten per gemeente wordt de productie per diersoort en per element $\mathrm{N}, \mathrm{P}$, organische stof $(\mathrm{C})$, basen, sulfaat, chloor en zware metalen als invoer aan het model opgegeven. De resultaten worden per gemeente geaggregeerd naar de productie van runder-, varkens-, 
pluimvee- en weidemest. De overige mestcategorieën uit GIAB-plus zijn als volgt toebedeeld: schapen-, geiten- en paardenmest is toegevoegd aan rundermest (krijgt bestemming gras) en de overige mestcategorieën (zoals nertsen- en konijnenmest) zijn toegevoegd aan pluimveemest (krijgt bestemming bouwland/overig). De categorie overige rundermest bestaat voor ca. $90 \%$ uit schapenmest en ca. $10 \%$ uit geitenmest (in termen van $\mathrm{N}$-excretie). Paardenmest is weliswaar toegekend aan de categorie overige rundermest, maar omdat deze mest deels in champost terechtkomt en dus via overige organische producten op de bodem wordt gebracht, wordt paardenmest niet meegenomen voor het berekenen van de bodembelasting met dierlijke mest. Daar waar het gaat om de emissie naar de atmosfeer (ammoniak, methaan, fijnstof en geur) wordt wel rekening gehouden met paarden.

Op basis van de arealen met gewassen (afgeleid van STONE en CBS) wordt de plaatsingsruimte bepaald. Dit gebeurt op basis van geldende $\mathrm{N}$ - en $\mathrm{P}$-normen voor het betreffende jaar. Voor $\mathrm{N}$ is dit vooral afhankelijke van areaal gras en bodem (derogatie) en voor $\mathrm{P}$ van afhankelijk van de $\mathrm{P}$ status van de bodem en het gewastype. De P-status is of gebaseerd op de berekende P-status (in geval van scenario's) of afgeleid van de RVO-data (voor de actuele situatie).

De toedieningsprocedure binnen een gemeente is als volgt:

- start met een minimale kunstmest gift een gift van overige organische meststoffen;

- verdeel de weidemest (homogeen) over het areaal grasland binnen de gemeente;

- dien rundermest toe aan grasland tot maximaal de gebruiksnorm;

- verdeel de eventueel overblijvende rundermest tezamen met de overige mest over maïs en overig bouwland maximaal tot de gebruiksnorm;

- indien er mest overblijft wordt de eventueel resterende ruimte verder opgevuld;

- per gemeente wordt vastgesteld of er sprake is van een overschot of resterende plaatsingsruimte, waarbij rekening wordt gehouden met acceptatiegraden;

- overschotten per gemeenten worden geaccumuleerd en vervolgens verminderd met een a-priori opgelegde verwerking en export naar het buitenland en emissiearme verwerkingscapaciteit.

De mestoverschotten per gemeente worden getransporteerd naar de gemeentes met plaatsingsruimte rekening houdend met de afstand en de acceptatiegraden. Daar worden de overschotten uitgereden. Is er in dat geval nog sprake van een overschot, dan wordt dit overschot geschaald naar de productie in de overschotgebieden afgezet in de overschotgebieden. De hoeveelheid benodigde kunstmest wordt berekend op basis van de werkzame hoeveelheid $\mathrm{N}$ die is toegediend als dierlijke mest, de gebruiksnorm en een minimale kunstmestgift.

\subsubsection{Modelinput}

De input van het model bestaat in grote lijnen uit:

- gedetailleerde ruimtelijke gegevens ten aanzien van bodem (bodemtype, C, N, P en metaal gehaltes), hydrologie, landgebruik en gewassen die grotendeels afkomstig zijn uit beschikbare nationale GIS-datasets:

- bodemkaart (geclusterde 1:50 000 bodemkaart)

- landgebruik (STONE voor de ruimtelijke verdeling, CBS voor de absolutie hoeveelheid)

- geografisch expliciete landbouwtellinggegevens, met o.a. het aantal dieren per bedrijf en staltype (GIAB-plus) met daarin:

- dieraantallen

- staltype

- locatie van stallen

- excretie -, emissie-, nitrificatie- en denitrificatiefactoren

- emissiefactoren, excreties en de verdeling van de mest over weide- en stalmest zijn afkomstig uit NEMA (Van Bruggen et al., 2014).

- normen ten aanzien van maximale mestgiften voor $\mathrm{N}$ en $\mathrm{P}$.

- acceptatiegraden voor dierlijke mest op basis van de berekende acceptaties uit de mestverwerkingspercentages

- derogatie (RVO)

- mestverwerking en export (CBS)

- gewasopnames (CBS)

- hydrologische fluxen gebaseerd op STONE 


\subsubsection{Modeloutput}

Voor de mestproductie wordt gebruik gemaakt van Giab-plus dieraantallen, NEMA excretie en NEMA emissiefactoren. Mestplaatsingsruimte wordt bepaald op basis van CBS-arealen. Verder wordt rekening gehouden met mestexport en mestverwerking. Transport van dierlijke mest wordt berekend op gemeenteniveau (van overschot gemeentes naar tekort gemeentes), de uiteindelijk dierlijke mestverdeling wordt bepaald op diverse schaalniveaus, variërend van perceelsniveau tot postcode 4-niveau.

\subsubsection{Scenario's/maatregelen}

INITIATOR kan de effecten van management en beleidsmaatregelen (zowel nationaal als regionaal) op excreties, emissies en bemesting (zowel kunstmest dierlijke mest als overige organische meststoffen) doorrekenen. Het betreft zowel ex-ante- als ex-postevaluaties. Het gaat hierbij onder andere om aanpassingen ten aanzien van de mestproductie (zoals dieraantallen, rantsoensamenstelling en mestbe- en verwerking), nutriëntenmanagement (zoals bemestingsniveau, beweidingsregime en gewasrestenbeheer) en ammoniakemissie (zoals staltypen, opslagtype en mesttoedieningstechniek).

\subsubsection{Afstemming en operationele aspecten}

\section{Relatie met andere modellen}

INITIATOR maakt gebruik van resultaten van de volgende modellen:

- STONE wat betreft de ruimtelijke schematisatie en bodem- en hydrologiegegevens.

- NEMA: voor beschrijving en parametrisatie van de ammoniakemissie.

- GIAB plus: wat betreft de geografisch expliciete landbouwtellinggegevens per bedrijf.

De uitvoer van INITIATOR wordt gebruikt door:

- OPS: voor het berekenen van de $\mathrm{NH}_{3}$ depositie op N2000-gebieden.

- AERIUS: voor het aanbrengen van meer ruimtelijk detail in de mesttoedieningsemissie van ammoniak.

\section{Onderhoud}

Het model wordt meerdere keren per ingezet voor opdrachtgevers, vnl. provincies. Daarnaast wordt het model ook ingezet in het kader van een Kennisbasisproject. Het onderhoud betreft vooral het operationeel houden van het model en het actualiseren van de procesbeschrijvingen en modelinvoer (zoals de GIAB- en NEMA-data, die jaarlijks geactualiseerd worden).

Het onderhoud en de actualisatie vinden plaats als regulier onderdeel van de projecten waarbinnen het model wordt ingezet. Globaal is voor het up-to-date houden van het model ca. $€ 10.000$ per jaar nodig.

Voor het volledige zelfstandig, zonder ondersteuning van externe projecten, is ca. $€ 15.000$ per jaar nodig

\section{Kwaliteitsborging}

De wetenschappelijke borging is geregeld via diverse peer-reviewed publicaties zowel op het gebied van nationale en regionale toepassingen, validatie en onzekerheden (zie referenties).

Ten behoeve van de kwaliteitsborging wordt de laatste hand gelegd aan een uitgebreide Nederlandstalige documentatie.

Op het model wordt versiebeheer toegepast en er is een beheerder voor het model aangewezen.

\section{Zelfevaluatie}

Geef een evaluatie van de sterke en zwakke punten van het model.

Sterke punten:

- Flexibel inzetbaar model met transparante procesbeschrijvingen.

- Modelaanpassingen, zoals het invoeren van extra maatregelen, zijn vrij eenvoudig uit te voeren. 
- Sluit aan bij de landelijke informatie ten aanzien van landbouwgegevens (landbouwtelling, GIAB), methodiek voor $\mathrm{NH}_{3}$ emissie (NEMA), depositie berekening (OPS, PAS) en hydrologie (STONE/NHI).

- Flexibel schaalniveau, variërend van perceel tot heel Nederland.

- De naar het nationale schaalniveau geaggregeerde modeluitvoer is consistent met de landelijke cijfers va het CBS/EmissieRegistratie.

- het model is gepubliceerd in peer-reviewed tijdschriften.

Zwakke punten:

- Verandering in landgebruik is niet dynamisch meegenomen. Hiervoor wordt gebruikgemaakt van de (gefixeerde) STONE-informatie.

- Aannamen dat gebruiksnormen voor $100 \%$ worden opgevuld, en dat kunstmest daarmee een restpost is.

- Gewasopname van nutriënten is relatief generiek, en opgelegd. Er is geen interactie met nutriëntenbeschikbaarheid.

- De toepassing is voorbehouden aan een specialist/onderzoeker. Er is geen externe versie beschikbaar.

- Het model rekent op jaarbasis, waardoor het lastig is gedetailleerde managementmaatregelen mee te nemen.

- Economische aspecten ten aanzien van mestverwerkings- en mesttransportberekeningen worden niet meegenomen.

De verdeling over percelen. Hiervoor geldt dat normen worden opgevuld, generiek over het bedrijf. Er zit geen teeltvoorkeur, afstandsvoorkeur of draagkracht (bodem en Gt-afhankelijke) voorkeur in de verdeling van dierlijke en kunstmest.

In Tabel 3 is een overzicht gegeven van verschillen en overeenkomsten tussen de twee op dit moment operationele mestverdelingsmodellen.

Tabel 3 Overzicht van de verschillen/overeenkomsten tussen de mestproductie en mestverdelingsmodule van de modellen MAMBO en INITIATOR2.

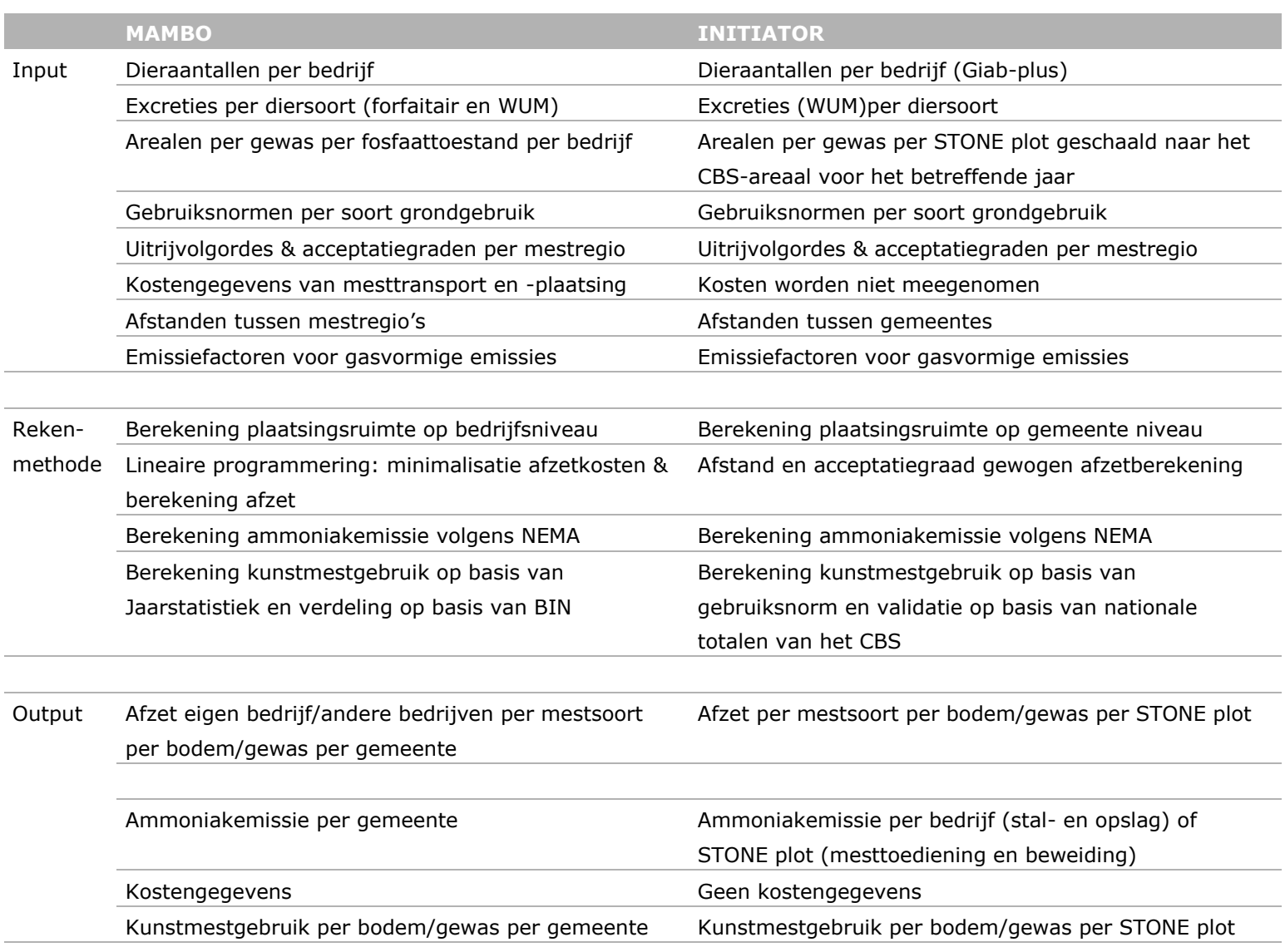




\subsection{Overige}

Wat betreft overige mestverdelingsmodellen is de spoeling dun. Een van de eerste mestverdelingsmodellen dat in Nederland is ontwikkeld, betreft het model SLAPP (Van Walsum, 1988). Het model SLAPP betreft een LP-model waarmee op gebiedsschaal bemestingsscenario's gegenereerd kunnen worden. Dit met als doel om de maximale hoeveelheid af te zetten dierlijke mest te berekenen, gegeven de te verwachten veranderingen in de landbouw, zoals het streven naar het verminderden van de mestoverschotten en het aanscherpen van de milieuvoorschriften. Later zijn binnen Nederland nog de modellen CLEAN, ontwikkeld bij het RIVM (Van Tol et al. 2002) en het REMmodel, ontwikkeld bij Wageningen Livestock Research (De Mol en Hilhorst, 2003) bijgekomen. Maar beide modellen worden niet meer gebruikt en zijn niet meer actueel. Het CLEAN-model is ontwikkeld als eerste mestverdelingsmodule, voordat overgestapt werd op MAMBO, voor STONE. In een in 2002 uitgevoerde plausibiliteitsstudie werd door Overbeek et al. (2002) vastgesteld dat verzamelde gegevens onvoldoende representatief zijn voor de berekening van regionale gemiddelden (bij het gebruik van dierlijke mest). Op basis van een vergelijking van de CLEAN-resultaten met die van het model MAM (Groenwold et al. 2003), voorganger van MAMBO, werd o.a. geconcludeerd dat verschillen vooral het gevolg zijn van afwijkende ruimtelijke resoluties en dat de rekenregels voor de verdeling van mest over gewassen en de acceptatie van mest door akkerbouwers in beide modellen onvoldoende getoetst zijn aan de praktijk.

Internationaal is er eveneens vrij weinig beschikbaar. Een van de weinige mestverdelingsmodellen in het buitenland betreft een model voor Noordwest-Duitsland. Het gaat hier om een in GAMS ontwikkeld LP-model en betreft vooral scenario analyses (https://www.mssanz.org.au/modsim2015/B4/biberacher.pdf).

\subsection{Adviezen}

Op basis van de uitkomsten van de workshop en de inventarisatie van huidige mestverdelingsmodellen wordt hieronder een overzicht gegeven van de belangrijkste eisen, criteria en overige aandachtspunten ten aanzien van de mestverdelingsmodules. Hierbij wordt achtereenvolgens ingegaan op de modeleisen, datagebruik en -beschikbaarheid, afstemming tussen organisaties en beleidssporen en aansturing en organisatiestructuur.

\section{Modeleisen:}

- Het is van het grootste belang dat in de mestverdelingsmodule de gehele mestketen van excretie van dierlijke mest tot en met de toediening van dierlijke mest, kunstmest en overige organische producten wordt meegenomen. Dit is nodig om consistentie, zowel binnen een beleidsspoor als tussen beleidssporen, te waarborgen.

- Geschikt voor zowel ex-post- als ex-anteanalyses.

- Bij ex post gaat het vooral om de huidige meststromen binnen en tussen regio's zo goed mogelijk in kaart te brengen, idealiter tot op perceelniveau.

- Detail informatie is vooral gewenst vanuit waterschappen/provincies en voor de PAS (mesttoediening).

- Bedenk hierbij dat dit mogelijk nu nog onzeker is, maar gezien de toekomstige ontwikkelingen, waarbij boeren op perceelniveau informatie digitaal beschikbaar hebben, zal het steeds betrouwbaarder/realistischer worden om dit schaalniveau te hanteren (zie ook hierboven).

- Bij ex ante gaat het om:

- Verandering in mestbeleid of GLB en het effect van de autonome ontwikkelingen.

- Verandering/aanpassing in het gedrag van de landbouwonderneming ten gevolge van de opgelegde veranderingen.

- Het opnemen van gedetailleerde microsimulatiemodellen (waarbij de financieel-economische situatie van individuele bedrijven wordt meegenomen) t.b.v. boerenbeslissingen in een mestverdelingsmodule is niet noodzakelijk/wenselijk. Indien gewenst/noodzakelijk, wordt geadviseerd om de benodigde informatie af te leiden op basis van toepassing van bestaande standalone modellen (bijv. de micro-modellen als FLAME en FES om gedrag te optimaliseren of 
simuleren en DRAM of een econometrisch marktmodel voor het bepalen van evenwichtsprijzen voor grond, quota en mest).

- Ongeacht de methodiek en/of het model dat wordt gebruikt, zal er sprake zijn van behoorlijke onzekerheid in de berekende mestgiften op gedetailleerde ruimtelijke schaal. Daarnaast is de kwaliteit van de landbouwstatistiek bepalend voor (i) de totale mestproductie en (ii) de beschikbare plaatsingsruimte.

Datagebruik en -beschikbaarheid:

Belangrijke aandachtspunten betreffen de bepaling van:

- Mestruimte, hoe om te gaan met: (i) grondsoortenkaart, PAl/Pw status: RVO.nl (ii) arealen (BRP en/of CBS rol niet getelde grond), (iii) derogatie en aangepaste bemestingspraktijk op agrarisch beheerde percelen voor natuur (beschikbaar bij RVO.nl).

- Acceptatiegraden: deze baseren op basis van aannamen (bijv. op basis van enquêtes) of achteraf berekende acceptatiegraden op basis van RVO-gegevens.

- Kunstmestgebruik: er zijn twijfels over de kwaliteit ervan. De kunstmeststatistiek van het WECR (gebruikt binnen NEMA) geeft een ander beeld dan de opgeschaalde kunstmestcijfers uit BIN.

- Een optie zou kunnen zijn om het kunstmestgebruik via de landbouwtelling waar te nemen. Deze landbouwtellinggegevens zijn eenvoudig te regionaliseren. Het gaat dan om het opnemen van een extra vraag in de Gecombineerde opgave. Om dit voor elkaar te krijgen, zal een hele toer worden, leert de ervaring. Kosten en baten dienen tegen elkaar afgewogen te worden, net als allerlei (tegengestelde) belangen.

- Beweiding en gebruik van mestsoorten. Hierbij worden vanuit NNM en AERIUS verschillende eisen gesteld. Zo vraagt AERIUS alleen om de $\mathrm{NH}_{3}$-emissie, terwijl NNM juist vraagt om de kwaliteit (o.a. i.v.m. werkingscoëfficiënten en organische stofgehalte) en kwantiteit (in termen van $N$ en $P$ ) van de diverse meststoffen.

- Export en verwerkingscijfers. Wat betreft de export en verwerking maakt zowel INITIATOR als MAMBO gebruik van de door CBS berekende export- en verwerkingscijfers, die als modelinput worden gebruikt. Voor de toekomst is het zaak om de beschikbare informatie beter te integreren met de modellen. Denk bijv. aan de regionalisatie van de export en verwerkingscijfers en het toename van de rol van mestverwerking.

- Flexibiliteit: Sorteer voor op de toekomst (aansluiten bij big data, open source, transdisciplinaire ontwikkelingen): boeren/loonwerkers etc. moeten (of doen dit gewoon omdat de mogelijkheid zich voordoet) meer en meer informatie op perceelniveau vastleggen. Zorg dat je hiervan gebruik kunt maken.

- Mesttoediening: Hoeveel gewassen neem je mee, maak je verschil tussen beteelde en onbeteelde bouwland, maak je verschil in uitrijperiode i.v.m. emissiefactoren.

- Overige organische meststoffen: informatie is slechts fragmentarische aanwezig.

- Excretiefactoren: bij RVO.nl zijn ook de ondernemers geregistreerd die aan bedrijfsspecifieke excretie (BEX) meedoen. Deze zouden als alternatief voor WUM-excretiefactoren gebruikt kunnen worden.

Afstemming tussen organisaties en beleidssporen:

- Afstemming met andere partijen en op modellen waarvan invoer wordt gebruikt (RVO, CBS, CPB, etc.).

- Afstemming met andere partijen die de uitvoer van het model gebruiken (PBL, ER, AERIUS).

- De relatie met RVO, CBS en BIN dient goed gewaarborgd te zijn. Dit is bij het huidige MAMBO goed geborgd (bestaande infrastuur). Maar omdat de structuur van databronnen zoals de arealen en diersoorten in de Landbouwtelling jaarlijks veranderen, vraagt het afstemmen met andere databronnen bij elke update vrij veel tijd.

- De relatie met NEMA, CDM, WUM en STONE dient goed gewaarborgd te zijn.

- Het is essentieel dat aangesloten wordt bij NEMA. Dat vormt immers het beginpunt van de keten. Het is echter wel zo dat NEMA op de nationale schaal rekent. Eventueel zouden regionalisaties ook in NEMA zelf kunnen gebeuren. Dit vergt enige ontwikkeltijd, maar daarna kost het weinig tijd om het jaarlijks te actualiseren. De vraag is echter of dit wel qua efficiëntie wel wenselijk is.

- De relatie met beleidssporen dient beter op elkaar te worden afgestemd. Zo zijn de (modelmatige) relaties tussen de beleidssporen ( $3^{\mathrm{e}}$ stroomgebiedsbeheerplannen KRW (SGPB, 2022-2027), $6^{\mathrm{e}}$ Nitraat Actieprogramma (2018-2021) ( $7^{\mathrm{e}}$ start tegelijk met $3^{\mathrm{e}}$ SGBP), $3^{\mathrm{e}}$ beheersplannen Natura 2000 (2020-2015)) maar zeer beperkt (zie paragraaf 2.2.1). 
Aansturing en organisatiestructuur:

- De aansturing van de modelontwikkeling en -toepassing dient goed geregeld te worden. Dit is zowel noodzakelijk wat betreft kwaliteit, consistentie en efficiëntie als wat betreft het beheersen van de kosten. Hierbij dienen zowel opdrachtgevers (I\&M, EZ), gebruikers (zoals PBL, ER, waterbeheerders), kennisinstellingen (WUR, ...) als gegevensbeheerders (zoals CBS en RVO) betrokken te worden.

- Zorg voor draagvlak bij stakeholders en eindgebruikers, zoals de Waterschappen, door deze te betrekken bij de NNM-ontwikkeling. 


\section{$5 \quad$ Conclusies en aanbevelingen}

In dit laatste hoofdstuk worden de belangrijkste conclusies en aanbevelingen beknopt gepresenteerd. Uit de reacties van deelnemers aan de workshop en de inventarisatie van wensen wordt geconcludeerd dat groot belang wordt gehecht aan:

- Streef naar een goedkoop en efficiënt in te zetten model voor mestverdeling, waarvan de kosten voor beheer, onderhoud, update en toepassing transparant zijn. Het beeld bestaat dat de werkwijze waarin MAMBO ter gelegenheid van bepaalde studies werd geüpdatet (ER 2013, EMW 2016), leidde tot kosten die zwaar drukten op het budget van de betreffende studies.

- Zorg voor consistentie in mestgegevens die gebruikt worden voor ex-post-en ex-antestudies.

- Maak eenduidige keuzes voor gegevensbronnen ten aanzien van gehalten in mest, kunstmestgebruik, landgebruik, emissiefactoren en dergelijke.

- Zorg voor een goede aansluiting op rekenmodellen die gebruikmaken van de mestgegevens, zowel wat betreft de ruimtelijke als de temporele schaal.

Op basis van de conclusies en de inventarisatie van wensen worden de volgende aanbevelingen gedaan. Hierbij wordt achtereenvolgens ingegaan op de organisatie, het schaalniveau, de relatie ex ante versus ex post, consistentie/borging en planning/operationaliteit.

Ten aanzien van de organisatie:

- Streef zo veel mogelijk naar consensus tussen kennishouders, waarbij de verschillende personen en instellingen die in het verleden bijdragen hebben geleverd in de informatievoorziening over bemesting betrokken zijn (CBS, WUR, PBL). Indien dit niet mogelijk blijkt te zijn, zorg dan voor een duidelijk besluit.

- Vraag als onderdeel van de ontwikkel- en testfase een plan voor beheer en onderhoud waarin duidelijk wordt welke kosten verbonden zijn aan (i) versiebeheer en up-to-date houden van documentatie, (ii) toepassingen voor EmissieRegistratie, Evaluaties van mest- en waterbeleid en regionale modeltoepassingen.

- Overweeg om gebruik te maken van Open Source code en data; dit draagt bij aan zowel kwaliteitsborging als transparantie. Het gaat om rekenprocedures, modelinvoer en modelresultaten binnen de mogelijkheden van niet-privacygevoelige informatie.

- Zorg daarnaast voor goede borging van privacygevoelige informatie.

Ten aanzien van het schaalniveau:

- Wat betreft de ruimtelijke schaal dient onderscheid gemaakt te worden in de rekenschaal en de presentatieschaal.

- De rekenschaal betreft primair die van het NNM:

- Voor de eerste landelijke beleidsstudies in 2018 is een rekenresolutie van CBS-gemeenteniveau voldoende, met daarbinnen onderscheid naar gewassen en grondsoorten.

- Bij de verdere doorontwikkeling van NNM naar regionale modellen is een rekenresolutie van $250 \mathrm{~m} \times 250 \mathrm{~m}$ gewenst.

- Daarnaast dient ook rekening gehouden worden met de rekenschaal van Aerius, die $100 \mathrm{~m} \times 100 \mathrm{~m}$ bedraagt. Hogere resolutie zal leiden tot zeer onzekere resultaten.

- Als presentatieschaal:

- Voor landelijke beleidsstudies is een presentatieschaal van de regionale KRW- waterlichamen voldoende.

- Op waterschapniveau is echter gedetailleerdere informatie nodig, o.a. ten aanzien van gewasspecifieke indeling en rekening houdend met herkenbare eenheden zoals polders en KRWwaterlichamen

- Wat betreft de temporele schaal is de (huidige) schaal van 1 jaar veelal afdoende. Idealiter is informatie op kwartaalbasis gewenst. Dit geeft een betere aansluiting bij de praktijk. Verder dienen de aannamen m.b.t. relatie tijdstip versus efficiëntie en gewasbehoefte goed te worden vastgelegd. 
Ten aanzien van ex-ante- versus ex-postscenario's:

- In de opdrachtomschrijving van dit project is gesuggereerd om onderscheid maken tussen (i) een uitgebreid model voor de huidige toestand en (ii) modellen om toekomstverkenningen mee uit te kunnen voeren.

- Dit omdat het naast elkaar in de lucht houden van twee operationele versies niet wenselijk is ten aanzien van de (i) onderlinge afstemming en continuïteit in koppelingen met het NNM; (ii) kosten en (iii) duidelijkheid in verantwoordelijkheden.

Ten aan zien van consistentie en borging:

- Zorg dat de hele mestketen (van excretie van dierlijke mest tot en met de toediening van dierlijke mest, kunstmest en overige organische producten) volledig in de mestverdelingsmodules is/wordt geïntegreerd.

- Zorg voor directe aansluiting op NNM en AERIUS (vermijd tweetrapsprocedure).

- Zorg voor goede borging en vereenvoudigen van de huidige (data)infrastructuur. Het jaarlijks updaten/synchroniseren van de data moet een formaliteit/automatisme worden. Op zich is dit vrij eenvoudig te realiseren door te zorgen dat de koppelingen zo veel mogelijk worden geautomatiseerd. Het enige wat dan jaarlijks zou moeten worden uitgevoerd, betreft het aanpassen van de gewijzigde categorieën in met name de landbouwstelling (RVO), de staltypen (NEMA) en methodewijzigingen (zoals gehanteerde categorieën).

- Zorg voor consistentie en afstemming bij alle aanpalende onderdelen, zoals vaststellen excretiefactoren, plaatsingsgraden, mestruimte, monitoring mestmarkt en vaststellen verplichte mestverwerkingspercentages.

- Dit geldt ook voor de rol van verwerking transport en normoverschrijding in geval van een tekort aan mestruimte en met name het kunstmestgebruik.

Ten aanzien van de planning en operationaliteit. De wens is om voor 2018 een operationele versie gereed te hebben. Om hieraan tegemoet te komen, wordt geadviseerd om:

- Zo veel mogelijk voort te bouwen op de huidige (data)structuur en eventuele wijzigingen stap voor stap in te voeren. Dit is met name ingegeven omdat het opzetten van een heel nieuw model niet realiseerbaar is binnen de beschikbare tijd, maar ook omdat hierin een groot risico schuilgaat, zoals het optreden van trendbreuken. Het is daarom verstandiger om voort te borduren op de huidige systemen.

- Cruciale aspecten die als eerste aangepakt dienen te worden:

- Het vereenvoudigen en automatiseren van de datastromen.

- Het borgen van de afstemming met NEMA, PAS en NNM door de gehele mestketen en de belangrijkste elementen ( $C, N, P, K$ en $S$ ) onder te brengen in de mestverdelingsmodule.

- Voor de aanlevering van uitspoelvrachten van andere stoffen dan nutriënten aan Emissie Registratie zijn behalve de hier genoemde nutriënten ook gehalten van zware metalen nodig en in de toekomst waarschijnlijk ook residugehalten van diergeneesmiddelen.

- Zorg voor een directe aansluiting bij het gewenste schaalniveau en differentiatie in mesttypen.

- Na 2018 zou dan vervolgengs gewerkt kunnen worden aan het verder uitbouwen van het systeem, zoals:

- Het geschikt maken voor scenarioanalyses (ex ante). Hierbij speelt o.a. mestverwerking en export een belangrijke rol.

- Het bedienen van eindgebruikers die behoeften hebben aan resultaten op gedetailleerdere schaal, zoals Waterschappen en provincies. 


\section{Literatuur}

De Koeijer, T.J., G. Kruseman, P.W. Blokland, M.W. Hoogeveen en H.H. Luesink, 2012. MAMBO visie en strategisch plan 2012 - 2015. Wettelijke Onderzoekstaken Natuur \& Milieu, Wageningen.

De Koeijer, T.J., H.H. Luesink, J.W. Kuhlman, L.F. Puister-Jansen en M.W. Hoogeveen, 2014. Regionale bodembelasting door stikstof en fosfaat, en ammoniakemissie 2013. LEI Wageningen UR, Den Haag.

De Koeijer, T.J., H.H. Luesink en P.W. Blokland, 2017. MAMBO-modelbeschrijving en uitgangspunten in het kader van de Evaluatie van de Meststoffenwet 2016. Factsheet / Wageningen Economic Research : 2017-044, Wageningen Economic Research.

De Mol, R.M. en M.A. Hilhorst, 2003. Methaan-, lachgas- en ammoniakemissies bij productie, opslag en transport van mest. Rapport 2003-03. IMAG, Wageningen.

De Vries, W., J. Kros, O. Oenema en J. de Klein, 2003. Uncertainties in the fate of nitrogen II: A quantitative assessment of the uncertainties in major nitrogen fluxes in the Netherlands. Nutrient Cycling in Agroecosystems 66 (1), 71-102.

EL\&I, 2012. Handboek Aerius 1.4, Concept. Ministerie van Economische Zaken, Landbouw en Innovatie, Programmadirectie Natura 2000, 78 pp.

Gies, T.J.A., J. van Os, R.A. Smidt, H.S.D. Naeff en E.C. Vos, 2015. Geografisch Informatiesysteem Agrarische Bedrijven (GIAB) : gebruikershandleiding 2010. Wettelijke Onderzoekstaken Natuur \& Milieu, Wageningen, $86 \mathrm{pp}$.

Groenendijk, P., L.V. Renaud, C. van der Salm, H.H. Luesink, P.W. Blokland en T.J. de Koeijer, 2015. Nitraat en $N$ - en P-uitspoeling bij de gebruiksnormen van het 5de NAP : modelberekeningen met MAMBO en STONE. Alterra Wageningen UR, Wageningen.

Groenendijk, P., E. van Boekel, L. Renaud, A. Greijdanus, R. Michels en T. de Koeijer, 2016. Landbouw en de KRW-opgave voor nutriënten in regionale wateren : het aandeel van landbouw in de $K R W$ opgave, de kosten van enkele maatregelen en de effecten ervan op de uit- en afspoeling uit landbouwgronden. Wageningen Environmental Research, Wageningen.

Groenwold, J.G., D.A. Oudendag, H.H. Luesink en H.C.J. Vrolijk, 2003. Het Mest- en Ammoniakmodel: Documentatierapport. In prep. LEI, Den Haag.

Kros, J., K.F.A. Frumau, A. Hensen en W. De Vries, 2011. Integrated analysis of the effects of agricultural management on nitrogen fluxes at landscape scale. Environmental Pollution.

Kruseman, G., H.H. Luesink, P.W. Blokland, M.W. Hoogeveen en T.J. de Koeijer, 2013. MAMBO 2.x : design principles, model structure and data use. Wettelijke Onderzoekstaken Natuur \& Milieu, Wageningen.

Lesschen, J.P., I.G. Staritsky en G.L. Velthof, 2011. Verkenning grootschalige toepassing van mineralenconcentraten in Nederland : effecten op nutriëntenstromen en emissies. Alterra, Wageningen, $110 \mathrm{pp}$.

Lesschen, J.P., B. Eickhout, W. Rienks, A.G. Prins en I. Staritsky, 2009. Greenhouse gas emissions for the $E U$ in four future scenarios. WAB Report 500102 026. PBL, Bilthoven.

Metz, D., 2015. Aerius calculator; Toelichting toepassingsbereik en beschrijving rekenmethode. Ministerie van Economische Zaken, Utrecht, 19 pp.

Overbeek, G.B.J., A.H.W. Beusen, P.C.M. Boers, G.J. van den Born, P. Groenendijk, J.J.M. van Grinsven, T. Kroon, H.G. van der Meer, H.P. Oosterom, P.J.T.M. van Puijenbroek, J. Roelsma, C.W.J. Roest, R. Rötter, A. Tiktak en S. van Tol, 2002. Plausibiliteitsdocument STONE 2.0 (Globale verkenning van de plausibiliteit van het model STONE versie 2.0 voor de modellering van uit- en afspoeling van N en P). RIVM, Bilthoven.

Schoumans, O.F., P.W. Blokland, P. Cleij, P. Groenendijk, T.J. de Koeijer, H.H. Luesink, L.V. Renaud en J. van den Roovaart, 2017. Ex-ante-evaluatie van de mestmarkt en milieukwaliteit. Wageningen Environmental Research, Wageningen.

Schroder, J.J., W. van Dijk en H. Hoek, 2011. Modelmatige verkenningen naar de relaties tussen stikstofgebruiksnormen en de waterkwaliteit van landbouwbedrijven. Plant Research International, Wageningen. 
Silvis, H.J., C.J.A.M. de Bont, J.F.M. Helming, M.G.A. van Leeuwen, F.H.J. Bunte en H. van Meijl, 2009. De agrarische sector in Nederland naar 2020 : perspectieven en onzekerheden.

LEI Wageningen UR, Den Haag.

Van Bruggen, C., A. Bannink, C.M. Groenestein, B.J. de Haan, J.F.M. Huijsmans, H.H. Luesink, S.M. Sluis, G.L. Velthof en J. Vonk, 2014. Emissies naar lucht uit de landbouw in 2012 : berekeningen van ammoniak, stikstofoxide, lachgas, methaan en fijn stof met het model NEMA. Wettelijke Onderzoekstaken Natuur \& Milieu, Wageningen, 79 pp.

Van den Roovaart, J., E. Meijers, R. Smit, P. Cleij, F. van Gaalen en S. Witteveen, 2012. Landelijke pilot KRW-Verkenner 2.0; Effecten van beleidsscenario's op de nutriëntenkwaliteit. Deltares, Utrecht.

Van der Hilst, F., J.P. Lesschen, J.M.C. van Dam, M. Riksen, P.A. Verweij, J.P.M. Sanders en A.P.C. Faaij, 2012. Spatial variation of environmental impacts of regional biomass chains. Renewable and Sustainable Energy Reviews 16 (4), 2053-2069.

Van der Salm, C., R. Dupas, R. Grant, G. Heckrath, B.V. Iversen, B. Kronvang, C. Levi, G. Rubaek en O.F. Schoumans, 2011. Predicting phosphorus losses with the PLEASE model on a local scale in Denmark and the Netherlands. J Environ Qual 40 (5), 1617-26.

Van Tol, S., G.J. van den Born, P.M. van Egmond, K.W. van der Hoek, N.J.P. Hoogervorst en O.M. Knol, 2002. CLEAN2.0, Model voor de berekening van stikstof- en fosfaatemissies uit de landbouw. Modelbeschrijving. RIVM Rapport 773004010. RIVM, Bilthoven, 76 pp.

Van Walsum, P.E.V., 1988. SLAPP : een rekenprogramma voor het genereren van bemestingsscenario's (betreffende dierlijke mest en stikstofkunstmest) ten behoeve van milieueffectonderzoek : versie 1.0. ICW, Wageningen, $26 \mathrm{pp}$.

Velthof, G.L. en J.J.M.v. Grinsven, 2006. Inzet van modellen voor evaluatie van de meststoffenwet: advies van de CDM-werkgroep harmonisatie modellen. Wettelijke Onderzoekstaken Natuur \& Milieu, Wageningen.

Velthof, G.L., C. van Bruggen, C.M. Groenestein, B.J. de Haan, M.W. Hoogeveen en J.F.M. Huijsmans, 2009a. Methodiek voor berekening van ammoniakemissie in Nederland. Rapport 70. Wettelijke Onderzoekstaken Natuur \& Milieu, Wageningen.

Velthof, G.L., D. Oudendag, H.P. Witzke, W.A.H. Asman, Z. Klimont en O. Oenema, 2009b. Integrated Assessment of Nitrogen Losses from Agriculture in EU-27 using MITERRA-EUROPE. J Environ Qual $38(2), 402-417$.

Velthof, G.L., T. Koeijer, J.J. Schröder, M. Timmerman, A. Hooijboer, J. Rozemeijer, C. van Bruggen en P. Groenendijk, 2017. Effecten van het mestbeleid op landbouw en milieu. Wageningen Environmental Research, Wageningen.

Vonk, J., A. Bannink, C. van Bruggen, C.M. Groenestein, J.F.M. Huijsmans, J.W.H. van der Kolk, H.H. Luesink, S.V. Oude Voshaar, S.M. Sluis en G.L. Velthof, 2016. Methodology for estimating emissions from agriculture in the Netherlands. Statutory Research Tasks Unit for Nature \& the Environment, Wageningen.

WUM, 2010. Gestandaardiseerde berekeningsmethode voor dierlijke mest en mineralen. Standaardcijfers 1990-2008. Centraal Bureau voor de Statistiek, Den Haag. 


\section{Bijlage 1 Programma, deelnemers en verslag van de workshop}

\section{Programma}

\section{Locatie}

Vergadercentrum Vredenburg

Vredenburg 19

3511 BB Utrecht

www.vredenburg19.nl (ca 10 min lopen va Utrecht CS)

\section{Programma}

Voorzitter: Albert Bleeker/PBL

Secretaris: Hans Kros/WENR

- 9:00-9:30 Inloop/ontvangst met koffie

- 9:30-9:45 Opening: aanleiding en wensen EZ/I\&M (Leo Oprel/ Wilbert van Zeventer)

- 9:45-10:00 Evaluatievragen/wensen t.a.v. mestverdelingsmodules PBL/Alterra (Aaldrik Tiktak/ Sietske van der Sluis)

- 10:00-10:15 Eisen vanuit het NNM t.a.v. mestverdelingsmodules Alterra/PBL (Piet Groenendijk)

- 10:15-10:30 Huidige situatie MAMBO (incl. aansluiting Stone + wensen/eisen t.a.v. (verplichte) rapportages) (WECR, PBL: Tanja de Koeijer/Harry Luesink)

- $10: 30-10: 45$ Overzicht van alternatieve mestverdelingsmodules (WENR: Hans Kros/ Jan Peter Lesschen)

- 10:45-11:00 Mest- en landbouwdata (incl. wensen/eisen t.a.v. rapportages)(CBS, RVO, ER: Arthur Denneman/Hendrik Mulder/Wim van de Maas)

- $11: 00-11: 15$ Koffie

- $11: 15-11: 25$ Wensen waterschappen en provincies (AVG, Aa en Maas: Gerard Ros/

- $11: 25-11: 45$ Wim van de Hulst) (nog niet toegezegd)

- 11:45-12:30 Inventarisatie en afstemming - Inventarisatie van eisen en criteria

- Afstemming en datagebruik

- 12:30-13:00 Afsluiting met broodjes en koffie 


\section{Deelnemers}

Tabel 4 Overzicht van genodigden van de Workshop scoping studie mestverdelingsmodellering in het Nationaal Nutriëntenmodel.

\begin{tabular}{|c|c|c|c|c|}
\hline Organisatie & Naam & e-mail & Specificatie & Aanwezig \\
\hline CBS & Arthur Denneman & a.denneman@cbs.nl & Landbouwtelling/NEMA & Ja \\
\hline Deltares & Timo Kroon & Timo.kroon@deltares.nl & Projectleider NHI & Nee \\
\hline$E Z$ & Stefan Breukel & s.j.m.breukel@minez.nl & PAS & $\mathrm{Ja}$ \\
\hline I\&M/ DGRW & Wilbert van Zeventer & Wilbert.van.zeventer@minienm.nl & & $\mathrm{Ja}$ \\
\hline PBL & Frank van Gaalen & Frank.vangaalen@pbl.nl & & $\mathrm{Ja}$ \\
\hline PBL & Sietske van der Sluis & Sietske.vanderSluis@pbl.nl & & Ja \\
\hline PBL & Marian van Schijndel & Marian.vanschijndel@pbl.nl & & Nee \\
\hline PBL & Albert Bleeker & Albert.Bleeker@pbl.nl & EMW & $\mathrm{Ja}$ \\
\hline RIVM & Wim van de Maas & wim.van.der.maas@rivm.nl & $\mathrm{ER}$ & $\mathrm{Ja}$ \\
\hline RIVM & Romuald te Molder & Romuald.te.molder@rivm.nl & ER/Kerngroep NNM & $\mathrm{Ja}$ \\
\hline RVO & Hendrik Mulder & hendrik.mulder@rvo.nl & RVO/Mestgegevens & $\mathrm{Ja}$ \\
\hline Waterschap(pen) & Gerard Ros & Gerard.ros@waternet.nl & Waterschap AGV & $\mathrm{Ja}$ \\
\hline Waterschap(pen) & Wim van de Hulst & WvanderHulst@aaenmaas.nl & $\begin{array}{l}\text { Waterschap Aa en } \\
\text { Maas }\end{array}$ & $\mathrm{Ja}$ \\
\hline WECR (LEI) & Harry Luesink & Harry.Luesink@wur.nl & MAMBO/BIN & Nee \\
\hline WECR (LEI) & Tanja de Koeijer & Tanja.deKoeijer@wur.nl & MAMBO/BIN & $\mathrm{Ja}$ \\
\hline WENR (Alterra) & Gerard Velthof & Gerard.velthof@wur.nl & NEMA/CDM & $\mathrm{Ja}$ \\
\hline WVL & Hannie Maas & Hannie.maas@rws.nl & Kerngroep NNM & Nee \\
\hline
\end{tabular}

\section{Verslag}

\section{Presentaties}

Opening: aanleiding en wensen EZ/I\&M (Leo Oprel):

Wens van EZ/I\&M is een mestverdelingsmodule die voldoet aan de kwalificaties:

- Goed, actueel, realistisch (beschrijft de huidige situatie zo goed mogelijk)

- Flexibel, ten alle tijden operationeel, snel te actualiseren met geringe inspanning, zonder al te veel detail

- Vormt een consistent geheel met de overige modellen/methodieken uit de gehele "mestketen" van productie $t / m$ emissies naar lucht (NEMA, ER) en water (ER)

- Een ruimtelijk detail dat afhankelijk is van de beoogde vraag.

Evaluatievragen/wensen t.a.v. mestverdelingsmodules (PBL) (Aaldrik Tiktak):

Huidig modelleninstrumentarium voor nutriëntenbelasting oppervlaktewater sluit niet goed aan op de KRW verkenner (te gebruiken voord de KRW evaluatie 2018):

- Weinig flexibel, vaste plots die niet aansluiten op KRW-waterlichamen

- Geen herkenning in de regio

- Verouderde hydrologie 
Het nieuw te ontwikkelen Nationaal Nutriënten Model (NNN, betreft onderdeel van het Nationaal Watermodel) moet deze knelpunten het hoofd bieden, waarbij het t.a.v. van de mestverdelingsmodule gaat om:

- Ex post (basisprognose): het zo goed mogelijk beschrijven van de werkelijke situatie

- Ex ante (toekomstverkenningen): een flexibel systeem, da minder eisen stelt ten aanzien van details

Beide systemen hoeven niet noodzakelijkerwijs in een model geïntegreerd te worden, maar dienen wel volledig consistent te zijn.

Wens is om het NNM in te zetten voor de voor KRW evaluatie 2018. Dit betekent dat het NNM beging 2018 operationeel moet zijn voor een landelijke toepassingen. Na 2018 kan dan gewerkt worden aan een nadere detaillering t.b.v. regionale toepassingen.

Opm. Wilbert van Zeventer/Stefan Breukel: integratie met beleidssporen ( $3^{\mathrm{e}}$ stroomgebiedsbeheerplannen KRW (SGPB, 2022-2027), $6^{\mathrm{e}}$ Nitraat Actieprogramma (2018-2021) ( $7^{\mathrm{e}}$ start tegelijk met $\left.3^{\mathrm{e}} \mathrm{SGBP}\right), 3^{\mathrm{e}}$ beheersplannen Natura 2000 (2020-2015)) moet efficiënter en effectiever worden.

Eisen vanuit het NNM t.a.v. mestverdelingsmodules (Piet Groenendijk):

Het landelijk nutriënten maakt nu gebruik van de volgende set van mestverdelingsinformatie:

- 1941-1970: Initialisatie op basis van aannamen

- 1971-1985: WSV

- 1986-2005: Clean, gedeeltelijk gebaseerd op MAM

- 2006-ev (inclusief scenario's): MAMBO

Wensen/aandachtspunten:

- Afstemming bemesting van gewassen/vruchtwisseling nodig

- Behoefte aan een consistente tijdreeks (focus op een specifiek jaar: risico's ivm toevallige effecten)

- Naast dierlijke mest ook aanvoer van overige organische mestproducten (zitten er nu niet in)

- Wat te doen met overbenutting van gebruiksruimte

- Consistentie in aannamen t.a.v. P-status (Pw/PAL ivm P-gebruiksnorm)

Huidige situatie MAMBO WECR (Tanja de Koeijer):

MAMBO wordt gebruikt voor ex post en ex ante evaluaties van (mest)beleid gericht op het in kaart brengen van de mestmarkt, bodembelasting en/of de emissie van ammoniak en stikstofgerelateerde broeikasgassen. De rekenbasis van MAMBO betreft een specifiek kalenderjaar.

Voor dieraantallen wordt gebruik gemaakt van de landbouwtelling (op basis van de hoofdvestiging), mogelijk betreft dit een overschatting. Dit wordt met de vernieuwde vraagstelling in de Landbouwtelling in de toekomst op basis van I\&R data waarschijnlijk beter.

Onderscheid in hoofd- en nevenvestigingen (kan worden) gemaakt op basis van Giab plus (Afhankelijk van de evaluatie worden de resultaten t.a.v. de excretie vermeld op basis van WUM of van forfaits. Kunstmest is gebaseerd op BIN voor de verdeling en op de kunstmestjaarstatistiek voor de absolute hoogte (In presentatie was dat fout aangegeven).

Het gepresenteerde kaartje m.b.t. P kunstmestgebruik per gemeente laat scherpe overgangen per gemeente/provincie zien.

Opm. Gerard Velthof: Kunstmest uit BIN, wijkt sterk af van kunstmest in NEMA. Vraagt dus om afstemming. Naschrift Tanja: zie eerder, de totale hoeveelheid is gebaseerd op de kunstmestjaarstatistiek en gelijk aan NEMA.

De aanpassing van de data t.g.v. een gemeentelijke herindeling vraagt veel extra tijd. Naschrift Tanja: De gemeentelijke herindeling moet bij elke update worden nagelopen. Maar verreweg de meeste tijd zit in het feit dat de structuur van databronnen zoals bijv. de arealen en diersoorten in de Landbouwtelling jaarlijks veranderen waardoor het afstemmen met andere databronnen bij elke update vrij veel tijd kost. 
Overzicht van alternatieve mestverdelingsmodules WENR (Hans Kros):

WENR (Alterra) maakt gebruik van twee modellen waarbij de mestverdeling op nationale schaal wordt berekend (MITERRA en INITIATOR). Beide methoden, die grotendeels uitgaan van dezelfde data en rekenmethoden, zullen de komen jaren worden geïntegreerd.

Voor de mestproductie wordt gebruik gemaakt van Giab-plus dieraantallen, NEMA excretie en NEMA emissiefactoren. Mestplaatsingsruimte wordt bepaald op basis van BRP. Verder wordt rekening gehouden met mestexport en mestverwerking.

Transport van dierlijke mest wordt berekend op gemeenteniveau (van overschot gemeentes naar tekort gemeentes), de uiteindelijk dierlijke mestverdeling wordt bepaald op diverse schaalniveaus, variërend van persceelsniveau tot postcode 4-niveau.

Voor toepassing van overige organische producten wordt gebuikt gemaakt van de CBS cijfers.

$\mathrm{N}$ en P Kunstmest: per plot opgevuld tot gebruiksnorm.

Opm. Tanja de Koeijer: Volgens BIN wordt de $\mathrm{N}$ gebruiksruimte grasland lang niet altijd opgevuld.

Mest- en landbouwdata-CBS (Arthur Denneman):

In de Nitraatrichtlijnrapportage (RIVM Rapport 2016-0076, tabellen in hoofdstuk 3) van de beschikbare mest- en landbouwdata en de wijze waarop het CBS daarvan gebruik maakt. De CBS meststatistieken worden gebruikt t.bv. StatLine \& Compendium Leefomgeving, CBS -

RIVM/Emissieregistratie (incl. NEMA) en werk voor derden (bijv. Nitraatrichtlijnrapportage \& Evaluatie Meststoffenwet).

Het ontsluiten van RVO vervoerbewijzen was in eerste instantie een hele toer geweest, maar is nu goed ingebed en geautomatiseerd. Dit geldt in zijn algemeenheid voor nieuwe informatiebronnen. Het voor de eerste keer ontsluiten is tijdrovend, maar als dat eenmaal is vastgelegd gaat het actualiseren snel.

Het CBS genereert zelf geen data en wat kwaliteit afhankelijk van de kwaliteit van de aangeleverde data. Zo zijn de kunstmestcijfers afkomstig van WECR (LEI), maar hier blijken wel twee versies van in omloop te zijn.

Om op te hoogte te blijven kan eenieder zich aanmelden voor de Nieuwsbrief Cor van Bruggen (via: cbgn@cbs.nl).

Mest- en landbouwdata-ER (Wim van de Maas):

ER rapporteert jaarlijks, maar eens per 3-4 jaar worden de (mesttoedienings)cijfers ruimtelijk verdeeld (kosten aspect, omdat MAMBO niet jaarlijks wordt geüpdatet omdat toepassing op projectbasis plaatsvinden, komen alle kosten voor een update ten laste van degene die het eerst met een opdracht komt. Zo kan het voorkomen dat ER opdraait voor alle kosten, terwijl overige gebruiker tegen relatief lage kosten aanvullende vragen kunnen stellen).

Mesttoediening betreft de meest onzekere factor bij het (ruimtelijk gedifferentieerd) bepalen van de stikstof depositie. Verder is het omgaan met trendbreuken is een lastig punt

MAMBO-STONE is kostbaar instrumentarium (MAMBO ca. 200k€ (voor update ammoniakemissie, uitbreiding percelen hoofd en nevenvestigingen, en neerschaling ammoniakemissie; een toepassing mbt effect bodembelasting kost ca. $25 \mathrm{kE}$ ) en STONE ca. $50 \mathrm{k} €$ per toepassing)

Opm. Wilbert van Zeventer: Eenduidige aansturing is noodzakelijk om (i) kosten te beperken en (ii) consistentie te vergroten.

Opm. Piet Groenendijk: Probleem is o.a. dat de kosten niet evenwichtig verdeeld worden onder de gebruikers. Als je bijv. kiest voor update om de twee jaar, waarbij de ene keer de kosten ten laste van ER en andere keer ten laste van EMW komen, krijg je al een evenwichtigere verdeling.

Wensen waterschappen en provincies (Gerard Ros, AVG; Wim van de Hulst Aa en Maas):

Doel vanuit waterschappen betreft de ecologische waterkwaliteit en dus niet zozeer de chemischewaterkwaliteit (waar het NNM zich op richt). Informatie uit NNM is ondersteunend aan creëren meer gebiedsinzicht en afleiden handelingsperspectief/ goede oplossingen voor verbetering waterkwaliteit. Doelschaal: Polder, afvoergebieden, KWR-waterlichamen

Om op deze schaal uitspraken te kunnen doen is een goed bemestingsmodel cruciaal. 
Wensen:

- Jaarlijks een ruimtelijk expliciet bestand met mesttoediening op perceelsniveau. Zowel voor de ex post als ex ante.

- Aansluiting bij de praktijk. Zo is er bij Waterschappen en overige regionale instanties veel praktijkinformatie beschikkaar die beter benut zou kunnen worden. Dit betreft bemestingshoeveelheid (bij beheerd pachtareaal, terreinbeherende organisaties), hydrologische informatie en mineralenbalansen

- Mest is breder dan dierlijke mest; kunstmest en overige organische producten zijn ook van groot belang

\section{Inventarisatie van eisen en criteria}

Lastig punt is de aanwezigheid van diverse beleidsmatige ruimtelijke eenheden. Zo is de doelschaal is sterk afhankelijk van instelling:

- PBL vnl landelijk

- ER vnl landelijk; maar ook regionaal irt N depositie

- Provincies: regionaal

- Waterschappen: op polderniveau/KRW Waterlichamen

Van belang is dat de Stuurgroep ER en stuurgroep NHI Initiatief neemt. De wijze waarop dit wordt uitgewerkt dient nog uitgewerkt te worden.

Verder is het zaak om de huidige situatie, met name qua datastromen, goed in kaart te brengen en op basis daarvan tot een advies te komen tot de wijze waarop de bestaande datastromen (beter) te stroomlijnen.

In het bijvoegde Excel-bestand (Inventarisatie_wensen_eisen.xlsx) is een start gemaakt met een overzicht van inventarisatie van wensen, eisen, knelpunten etc.

\section{Afspraken}

- Afgesproken is om de tabel met wensen, eisen, knelpunten etc. zo veel mogelijk te complementeren, door hiervoor doelgericht een aantal personen voor te benaderen.

- Het gaat hierbij om de volgende instellingen/personen:

- EZ: Leo Oprel/Stefan Breukel

- I\&M: Wilbert van Seventer

- PBL: Frank van Gaalen/Aaldrik Tiktak/Sietske van der Sluis

- CBS/RVO: Arthur Denneman/Hendrik Mulder

- Waterschappen/Provincies: Gerard Ros/Wim van der Hulst/Arnout Venekamp)

- RIVM-ER Wim van der Maas/Romuald te Molder

- En de volgende inventariserende vragen (zie Excel-bestand):

- Welk schaalniveau

- Wensen ten aanzien Basisprognose (ex post) en Toekomstverkenningen (ex ante)

- Flexibiliteit (t.a.v. te verwachten (nieuwe) vragen)

- Consistentie/afstemming (met overige beleidssporen)

- Operationele aspecten (Ontwikkeltijd, tijd/kosten reguliere en ad-hoc toepassingen, bestuurlijke aspecten)

- De vraag aan de hierboven genoemden, is om beknopt op deze vragen (mag ook breder uiteraard) te reflecteren. Dit kan middels een apart bestandje of direct in het mailbericht.

- De overige deelnemers zijn uiteraard van harte uitgenodigd om eveneens te reflecteren. 


\section{Bijlage 2 Verkenning van MITERRA en INITIATOR ten behoeve van inzet voor de NEMA}

Hans Kros

Jan Peter Lesschen

April 2011

In deze notitie wordt een overzicht gegeven van de wijze waarop de modellen MITERRA en INITIATOR de dierlijke- en kunstmestverdeling en de $\mathrm{NH}_{3}$-emissie berekenen. Daarnaast wordt aangegeven welke aanpassing moeten worden verricht om beide modellen geschikt te maken voor toepassing binnen NEMA.

Tabel 5 Overzicht van data, processen en schaalniveau van MITERRA en INITIATOR.

\begin{tabular}{ll} 
Onderdeel & MITERRA \\
Dieraantallen & GIAB data op postcode 4 niveau \\
& (33 categorieën) \\
\hline Landgebruik & BRP (bedrijfsregistratie percelen) op postcode \\
& 4 niveau (38 gewassen voor 2007$)$
\end{tabular}

\section{INITIATOR}

Per bedrijf voor de CBS/RAV categorieën.

4 niveau (38 gewassen voor 2007)

LGN data voor het jaar 2000 op Stone-plot resolutie (ca. 6000 unieke combinaties van bodem, grondwatertrap, bodemchemische kenmerken en landgebruik (zowel landbouw (grasland, maïs, overig bouwland) als natuur (sparrenbossen, dennenbossen, loofbossen, heide en onbemest grasland).

Stal- en opslagemissie Op postcode 4 niveau volgens NEMA Per bedrijf rekening houdend met staltype en methodiek diercategorie volgens GIAB. Met gebruikmaking van de emissiemethodiek uit WOt-rapport 70 (Velthof et al. 2009).

\begin{tabular}{|c|c|c|}
\hline Mestverdeling & $\begin{array}{l}\text { Mesttransport op provincieniveau } \\
\text { (optimalisatie op basis van beschikbare ruimte } \\
\text { en kosten voor transport) }\end{array}$ & $\begin{array}{l}\text { Mesttransport op gemeente niveau (rekening } \\
\text { houdend met transportafstand en } \\
\text { acceptatiegraden). Verdeling op } \\
\text { Stoneplotniveau }\end{array}$ \\
\hline Kunstmest & $\begin{array}{l}\text { Op basis van de ruimte tussen de geplaatste } \\
\text { mest en de gebruiksnormen voor } \mathrm{N} \text { en } \mathrm{P}\end{array}$ & $\begin{array}{l}\text { Op basis van combinatie van berekende } \\
\text { dierlijke mestgiften en het bemestingsadvies } \\
\text { uit de Meststoffenwet } 2006 \text {. }\end{array}$ \\
\hline Beweidingsemissie & $\begin{array}{l}\text { Op postcode } 4 \text { niveau volgens NEMA } \\
\text { methodiek }\end{array}$ & $\begin{array}{l}\text { Volgens berekende verdeling van weidemest } \\
\text { en de Velthof et al emissiefracties }\end{array}$ \\
\hline Toedieningsemissie & $\begin{array}{l}\text { Volgens berekende mestverdeling en NEMA } \\
\text { methodiek op postcode } 4 \text { niveau }\end{array}$ & $\begin{array}{l}\text { Volgens berekende verdeling van stalmest en } \\
\text { kunstmest en de toedieningstechniek uit } \\
\text { GIAB. Gekoppeld aan de WOt-rapport } 70 \\
\text { (Velthof et al. 2009). }\end{array}$ \\
\hline Overige stoffen & $\begin{array}{l}\mathrm{N}_{2} \mathrm{O}, \mathrm{CH}_{4}, \mathrm{NO}_{3}, \mathrm{NOx} \text {, bodem } \mathrm{C} \text { (evt. zware } \\
\text { metalen volgens MITERRA-Europe) }\end{array}$ & $\mathrm{N}_{2} \mathrm{O}, \mathrm{CH}_{4}, \mathrm{C}$, Zware metalen, Basen, fijnstof \\
\hline Koppeling met Stone & Geen & $\begin{array}{l}\text { Rekent voor Stone-plots. Gebruikt Stone- } \\
\text { hydrologie en bodemchemische en -fysische } \\
\text { data. }\end{array}$ \\
\hline Koppeling met GIAB & $\begin{array}{l}\text { Input data voor dieraantallen komen van } \\
\text { GIAB op PC4 niveau }\end{array}$ & $\begin{array}{l}\text { Gebruikt data op bedrijfsniveau; voor } \\
\text { dieraantallen, staltype en toedieningstechniek. }\end{array}$ \\
\hline Schaalniveau van inputs & Postcode 4 of provincieniveau & Variërend van puntniveau tot Stone-plots \\
\hline Schaalniveau van outputs & Postcode 4 en provincieniveau & $\begin{array}{l}\text { In het algemeen Stone-plots. Stalemissie } \\
\text { echter op bedrijfsniveau en } \mathrm{NH}_{3} \text {-depositie op } \\
250 \mathrm{~m} \text { gridniveau. }\end{array}$ \\
\hline
\end{tabular}


Tabel 6 Overzicht van operationele aspecten MITERRA en INITIATOR.

\begin{tabular}{|c|c|c|}
\hline Onderdeel & MITERRA & INITIATOR \\
\hline Wetenschappelijke borging & $\begin{array}{l}\text { Zie Lesschen et al. (2009) en Van der Hilst } \\
\text { et al. (2012). Daarnaast zijn er diverse } \\
\text { publicaties over het MITERRA-Europe model } \\
\text { (Velthof et al. 2009b; Lesschen et al. 2011). }\end{array}$ & $\begin{array}{l}\text { Diverse publicaties voor zowel landelijke } \\
\text { toepassing (De Vries et al. 2003) als regionale } \\
\text { toepassing (Kros et al., 2011) en validatie } \\
\text { (Kros et al. 2005). }\end{array}$ \\
\hline Onzekerheden & $\begin{array}{l}\text { Zijn niet specifiek gekwantificeerd voor } \\
\text { MITERRA. Echter andere studies geven al } \\
\text { redelijk inzicht in de onzekerheden van N } \\
\text { emissies. }\end{array}$ & $\begin{array}{l}\text { Voor N componenten gekwantificeerd, zie } \\
\text { De Vries et al. (2003). }\end{array}$ \\
\hline Kwaliteitsborging & $\begin{array}{l}\text { Er wordt gewerkt aan een betere } \\
\text { documentatie. Daarnaast is er het plan om } \\
\text { een SVN-systeem op te zetten, zodat alle } \\
\text { veranderingen goed gedocumenteerd blijven } \\
\text { en er met meerdere mensen aan het model } \\
\text { gewerkt kan worden. }\end{array}$ & $\begin{array}{l}\text { Er wordt gewerkt aan een uitgebreide } \\
\text { documentatie (De Vries et al. 2011). Op het } \\
\text { model wordt versiebeheer toegepast. }\end{array}$ \\
\hline
\end{tabular}

Tabel 7 Relatie met NEMA in de modellen MITERRA en INITIATOR.

\begin{tabular}{|c|c|c|}
\hline Onderdeel & MITERRA & INITIATOR \\
\hline Huidige relatie NEMA & $\begin{array}{l}\text { Voor de studie naar scenario's voor gebruik } \\
\text { mineralen concentraten is de NEMA methodiek } \\
\text { ingebracht, deze wordt een-op-een gevolgd. }\end{array}$ & $\begin{array}{l}\text { Voor een toepassing voor provincie Gelderland } \\
\text { is recentelijk emissiemethodiek uit WOt- } \\
\text { rapport } 70 \text { (Velthof et al. 2009) ingebouwd. } \\
\text { Dit betreft een voorloper van NEMA. }\end{array}$ \\
\hline Benodigde aanpassingen & $\begin{array}{l}\text { Voor NH3 geen aanpassingen nodig, voor } \\
\text { specifieke output, bijv. koppeling met STONE } \\
\text { plots moet wel een aggregatieprocedure } \\
\text { bedacht worden. }\end{array}$ & $\begin{array}{l}\text { Een } 1 \text { op } 1 \text { koppeling tussen de CBS/RAV } \\
\text { diercategorieën en de staltypen uit Giab met } \\
\text { de NEMA categorieën. }\end{array}$ \\
\hline $\begin{array}{l}\text { Eenmalige kosten voor } \\
\text { aanpassingen }\end{array}$ & $\begin{array}{l}\text { Hangt af van benodigde aanpassingen voor } \\
\text { output. }\end{array}$ & $\begin{array}{l}\sim € 20.000 \text {; inclusief documentatie en } \\
\text { terugkoppeling met NEMA ontwikkelaars. }\end{array}$ \\
\hline $\begin{array}{l}\text { Jaarlijkse kosten voor } \\
\text { aanpassingen }\end{array}$ & $\begin{array}{l}€ 5.000-€ 10.000 \text {, dit gaat uit van weinig } \\
\text { aanpassingen, en is excl. kosten voor nieuwe } \\
\text { data van GIAB en BRP. }\end{array}$ & $\begin{array}{l}\sim € 15.000 \text {, uitgaande van incorporatie van } \\
\text { nieuwe GIAB data, evt. aanpassing van } \\
\text { emissie en excretiefactoren en een landelijke } \\
\text { berekening van de emissiecijfers op basis van } \\
\text { de doorgevoerde aanpassingen. }\end{array}$ \\
\hline
\end{tabular}


Wageningen Environmental Research Postbus 47

6700 AA Wageningen

T 0317480700

www.wur.nl/environmental-research

Wageningen Environmental Research Rapport 2817

ISSN 1566-7197
De missie van Wageningen University \& Research is 'To explore the potential of nature to improve the quality of life'. Binnen Wageningen University \& Research bundelen Wageningen University en gespecialiseerde onderzoeksinstituten van Stichting Wageningen Research hun krachten om bij te dragen aan de oplossing van belangrijke vragen in het domein van gezonde voeding en leefomgeving. Met ongeveer 30 vestigingen, 5.000 medewerkers en 10.000 studenten behoort Wageningen University \& Research wereldwijd tot de aansprekende kennisinstellingen binnen haar domein. De integrale benadering van de vraagstukken en de samenwerking tussen verschillende disciplines vormen het hart van de unieke Wageningen aanpak. 



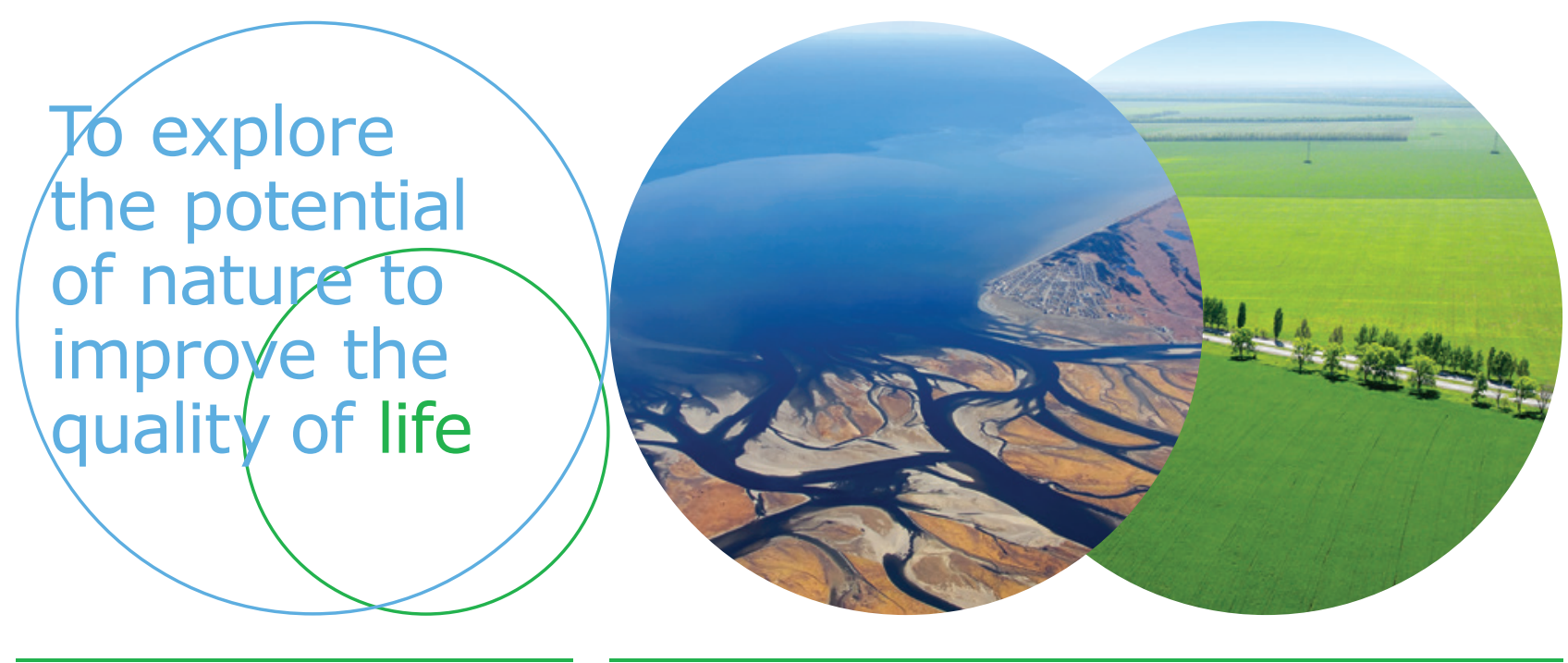

Wageningen Environmental Research Postbus 47

$6700 \mathrm{AB}$ Wageningen

T 317480700

www.wur.nl/environmental-research

Rapport 2817

ISSN 1566-7197
De missie van Wageningen University \& Research is 'To explore the potential of nature to improve the quality of life'. Binnen Wageningen University \& Research bundelen Wageningen University en gespecialiseerde onderzoeksinstituten van Stichting Wageningen Research hun krachten om bij te dragen aan de oplossing van belangrijke vragen in het domein van gezonde voeding en leefomgeving. Met ongeveer 30 vestigingen, 5.000 medewerkers en 10.000 studenten behoort Wageningen University \& Research wereldwijd tot de aansprekende kennisinstellingen binnen haar domein. De integrale benadering van de vraagstukken en de samenwerking tussen verschillende disciplines vormen het hart van de unieke Wageningen aanpak. 